\title{
Five-Membered Ring Peroxide Selectively Initiates Ferroptosis in Cancer Cells
}

Rachel P. Abrams ${ }^{1,2}$, William L. Carroll ${ }^{2 *}$, and K. A. Woerpel ${ }^{1 *}$

${ }^{1}$ Department of Chemistry, New York University, 100 Washington Square East, New York, NY

10003, USA; ${ }^{2}$ Laura and Isaac Perlmutter Cancer Center, New York University Langone

Medical Center, 522 First Avenue, Smilow Building 12 Floor, Room 1211, New York, NY

10016, USA.*e-mail: william.carroll@nyumc.org or kwoerpel@nyu.edu

\section{Supplementary Information}

\section{Table of Contents}

Pages

Supplementary Figures

Supplementary Discussion

Supplementary Methods

X-ray Crystallographic Information

Selected Spectra

$40-46$

Supplementary References

$47-49$ 


\section{Supplementary Figures}

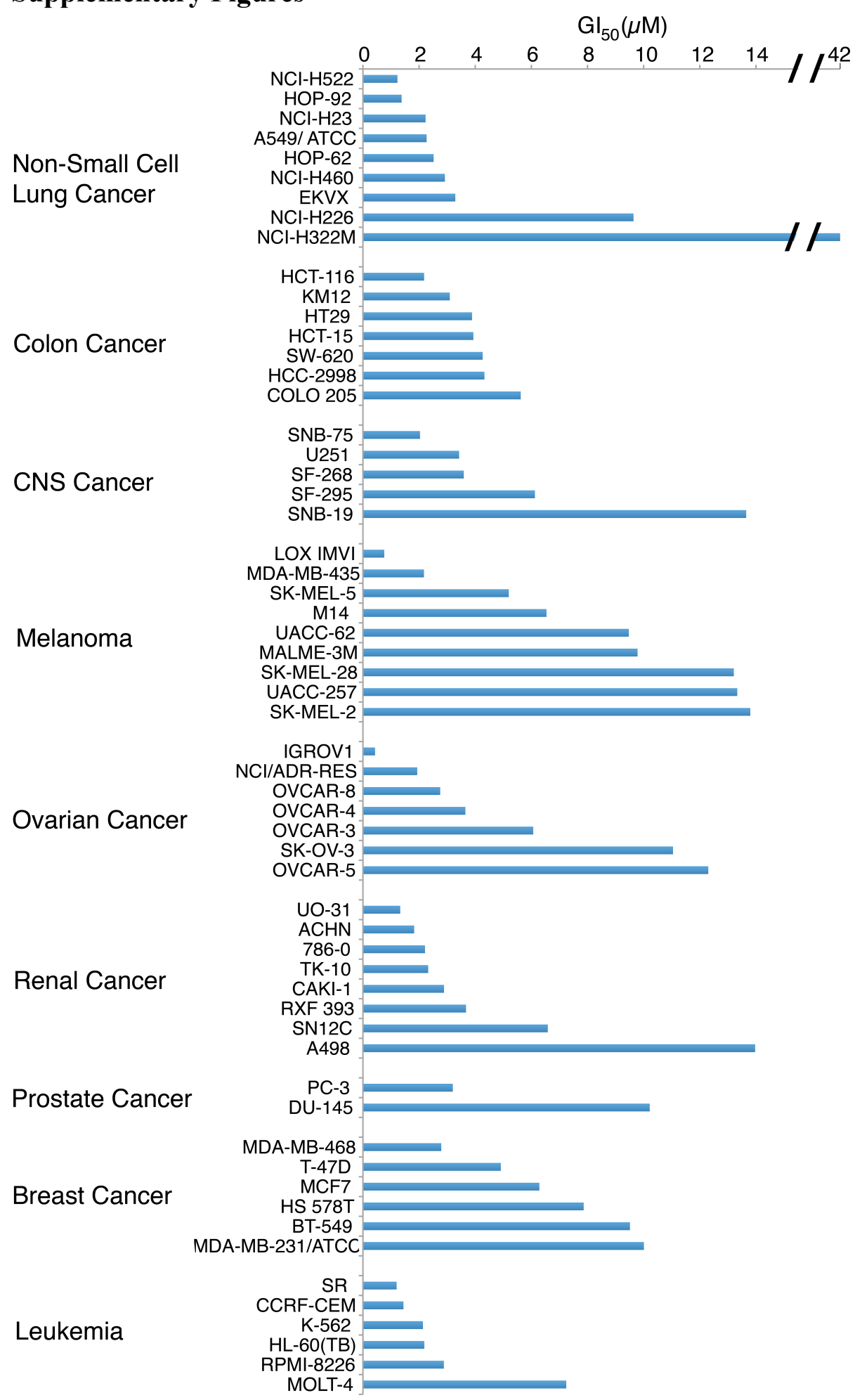

Supplementary Figure 1. The concentrations at which $50 \%$ of cell growth was inhibited $\left(\mathrm{GI}_{50}\right)$

grouped by tissue of origin to illustrate that $\mathrm{FINO}_{2}$ is both active and inactive in a range of cell 
lines from different tissues. Data obtained by the Developmental Therapeutic Program of the National Cancer Institute.
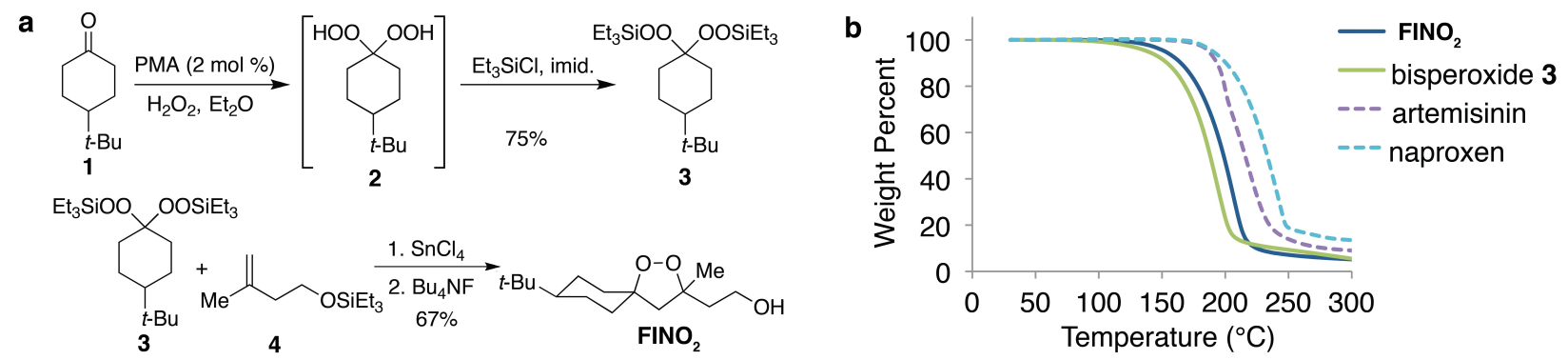

Supplementary Figure 2. Synthesis and stability. (a) Synthesis of $\mathrm{FINO}_{2}$; Phosphomolybdic acid (PMA), imidazole (imid.). (b) Thermogravimetric analysis. The thermal stability of $\mathrm{FINO}_{2}$ was corroborated by NMR analysis of a sample that had been heated to $150^{\circ} \mathrm{C}$.

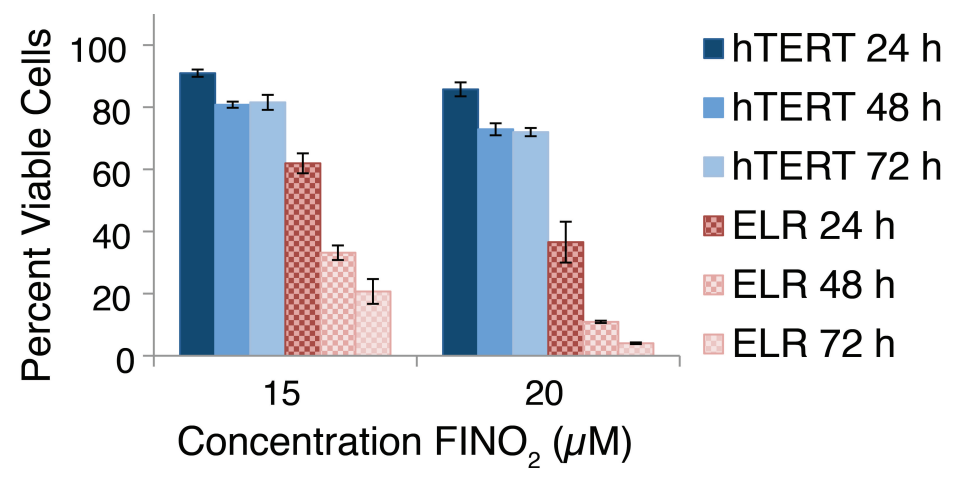

Supplementary Figure 3. Selectivity of $\mathrm{FINO}_{2}$ measured by Promega CellTiter-Glo ${ }^{\circledR}$ Luminescence Assay. Cell viability decreases for cancerous cells (ELR), but not non-canceous cells (hTERT) over time, resulting in the best selectivity being observed after 72 hours of treatment with $\mathrm{FINO}_{2}$. 

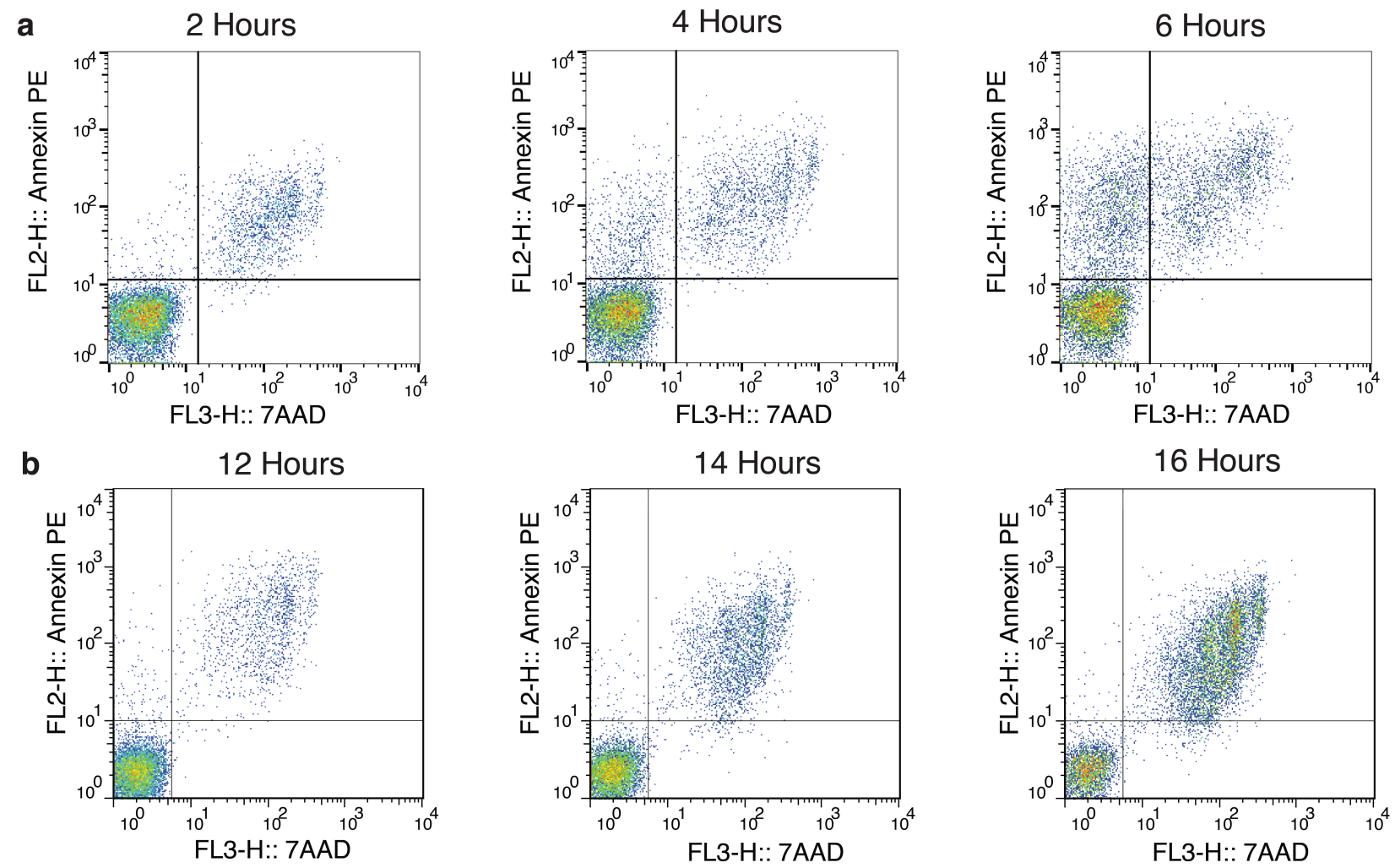

Supplementary Figure 4. Annexin V-PE and 7AAD apoptosis assay. a) Annexin V-PE staining is observed prior to 7AAD with $50 \mu \mathrm{M}$ of etoposide treatment at indicated time points. b) Annexin V-PE staining is not observed prior to 7AAD incorporation with $6 \mu \mathrm{M}$ of $\mathrm{FINO}_{2}$ treatment at indicated time points. 

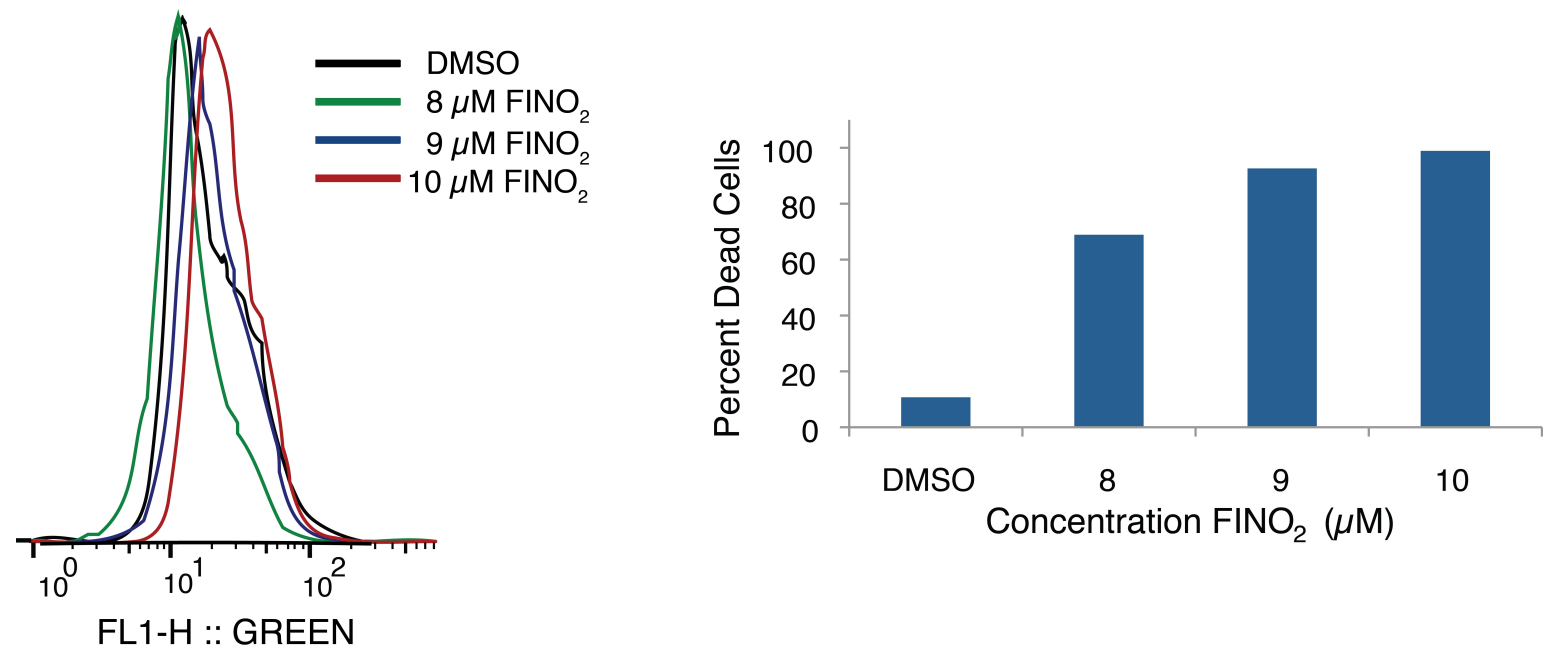

Supplementary Figure 5. The BioVision MitoCapture ${ }^{\mathrm{TM}}$ Mitochondrial Apoptosis Detection Kit showed a shift in green fluorescence. The shift in fluorescence was not observed until after the majority of the cells were dead, as indicated by Trypan Blue staining.

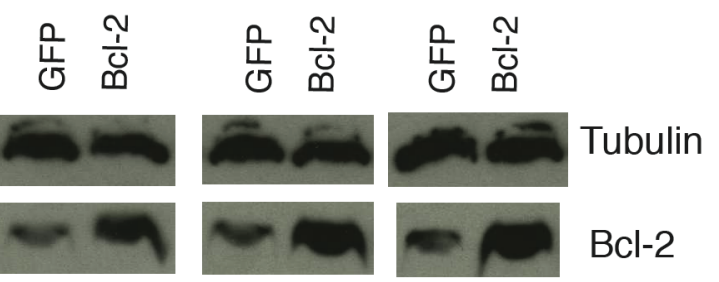

Supplementary Figure 6. Western blot showing overexpression of the bcl-2 protein in cells collected the day of experiment plating. 
a

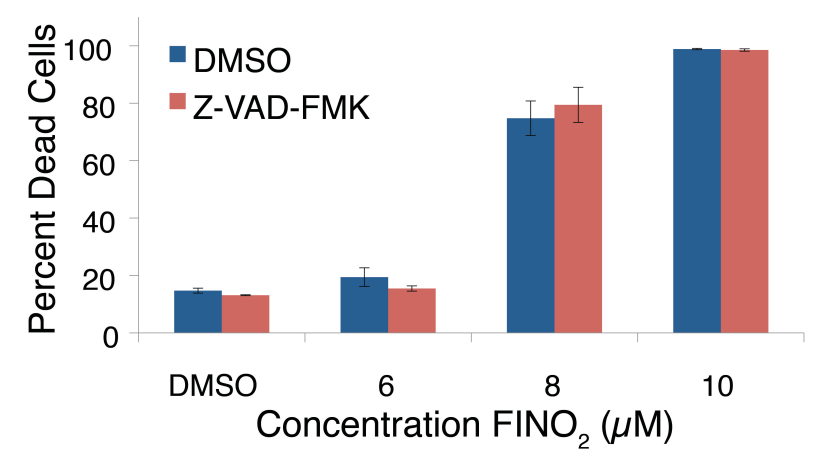

b

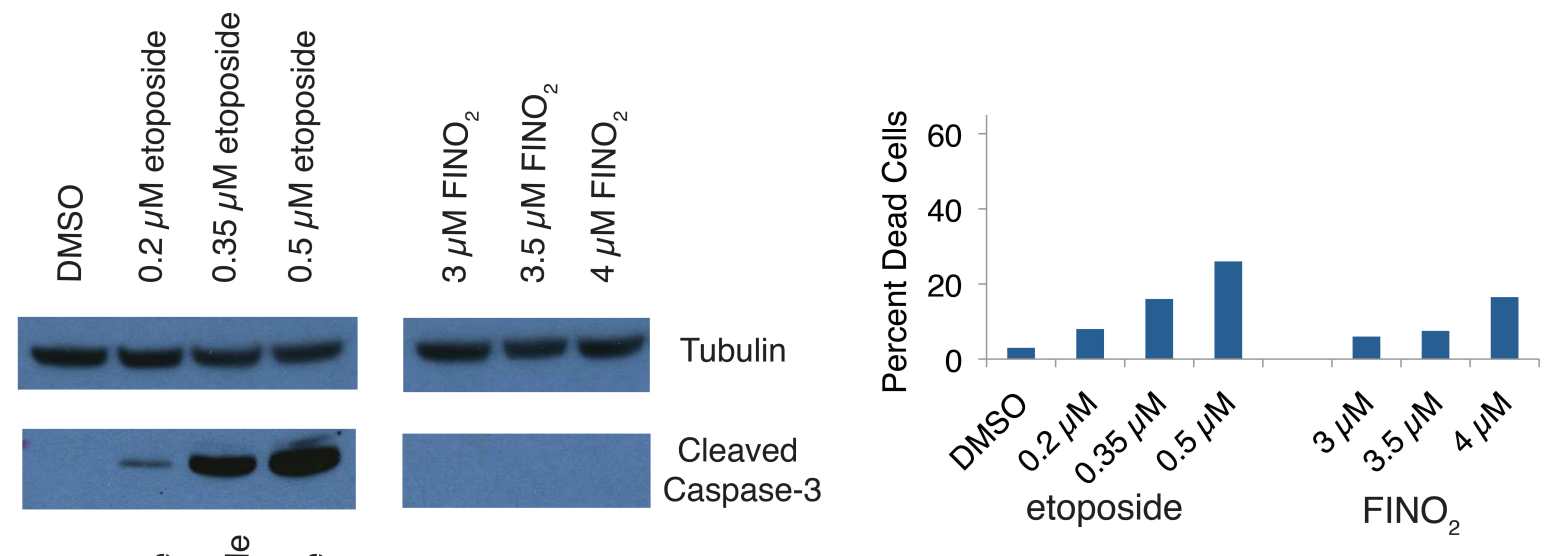

c

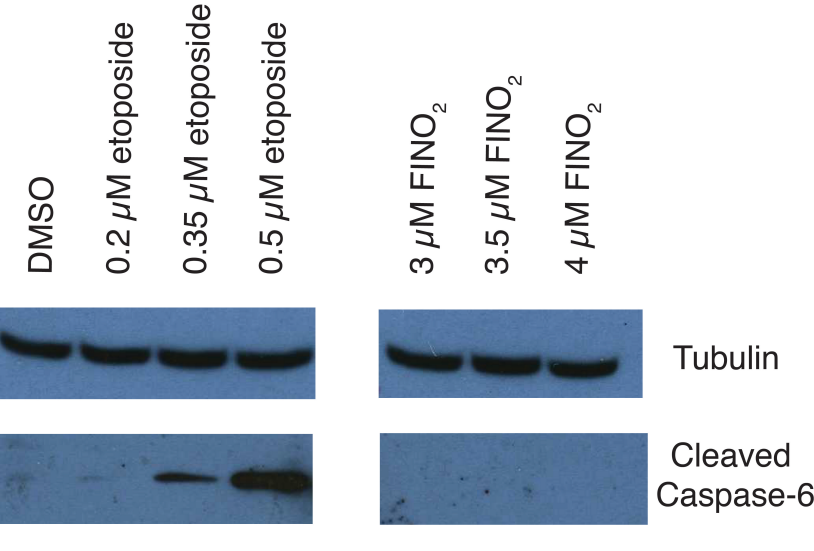

d
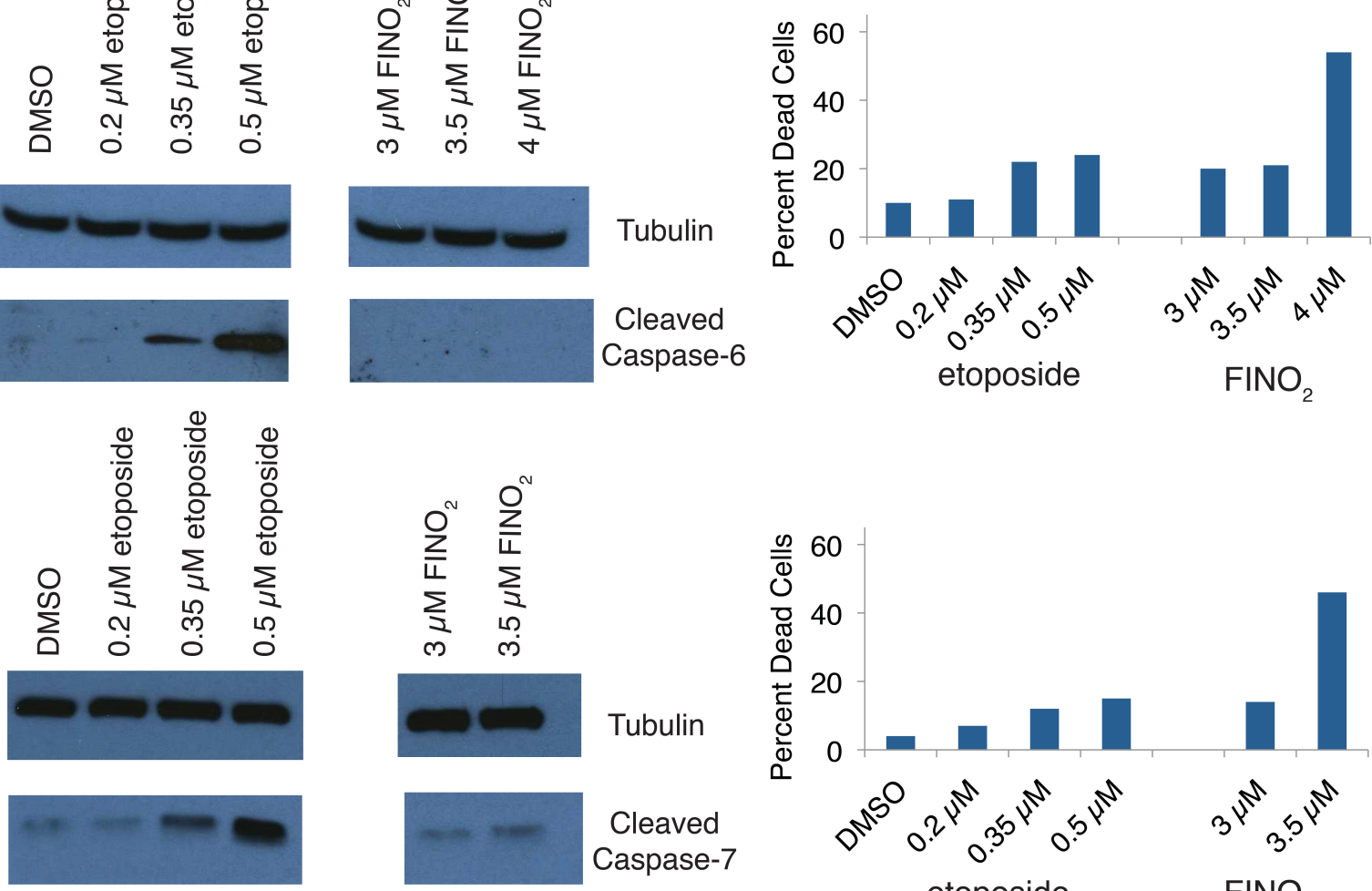

Cleaved

Caspase-7

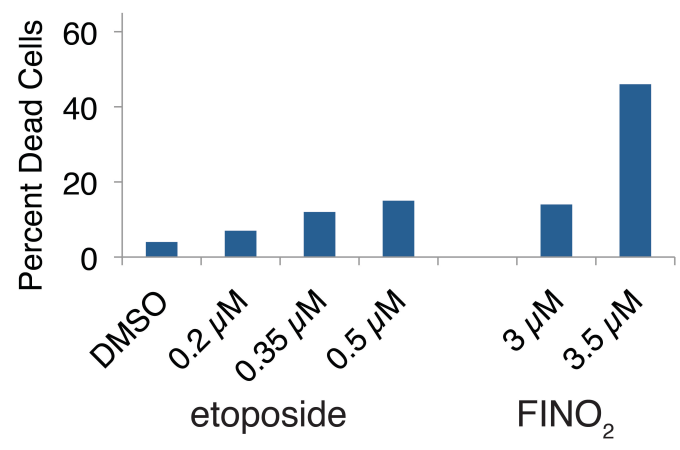


Supplementary Figure 7. Caspase activation is not involved in cell death induced by $\mathrm{FINO}_{2}$. (a) Pretreatment with $2.4 \mu \mathrm{M}$ of a pan-caspase inhibitor (Z-VAD-FMK) does not inhibit cell death. Percent dead cells indicate the Annexin V and 7AAD positive cell population. (b) Activation of executioner caspase- $3,-6$, or -7 was not observed by the detection of cleaved proteins by Western blot. Similar quantities of cell death induced by chemotherapeutic agents, such as etoposide, result in activation of executioner caspases. All caspase antibodies were used at 1:500 dilutions and incubated overnight. Tubulin was used at a 1:5000 dilution and incubated overnight. Trypan Blue staining was used to indicate cell death.

a

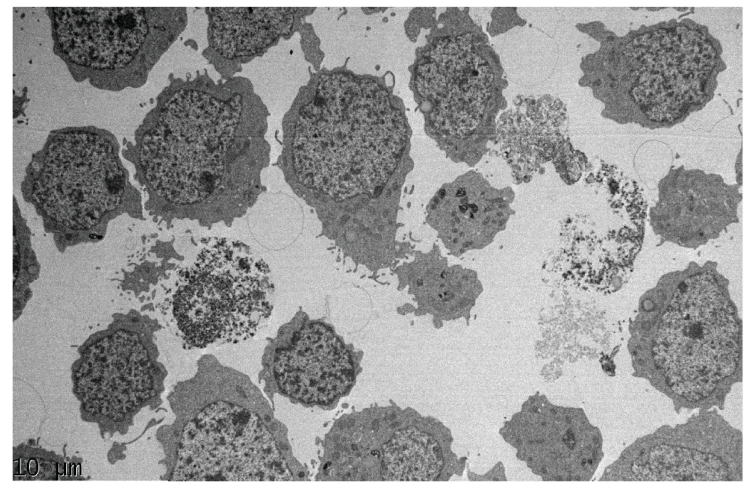

b

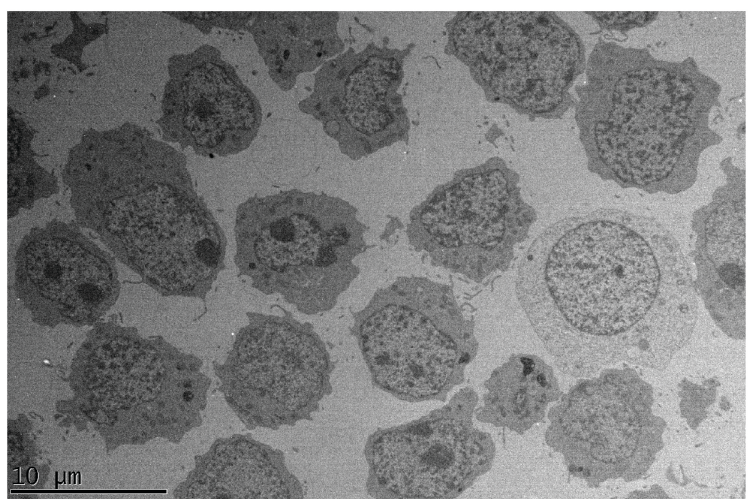

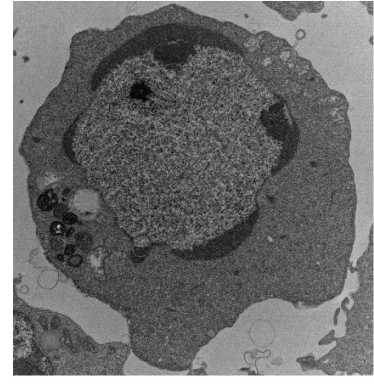

control cell undergoing apoptosis

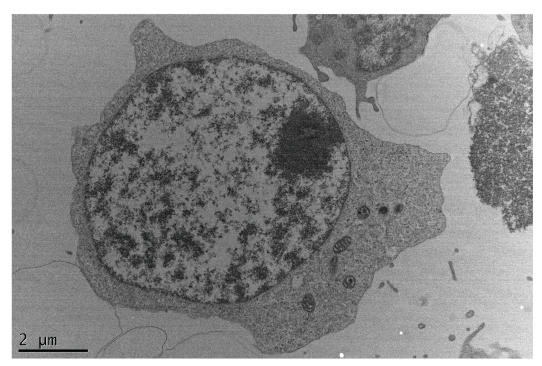

$\mathrm{FINO}_{2}$ treated cell undergoing ferroptosis

Supplementary Figure 8. Electron microscopy images of RS4;11 cells. a) Cells treated with vehicle only (DMSO) and example of RS4;11 cell undergoing apoptosis. b) Cells treated with 
$\mathrm{FINO}_{2}$ lacking hallmarks of apoptosis, necrosis, and autophagy (performed by the Microscopy Core at New York University Langone Medical Center).
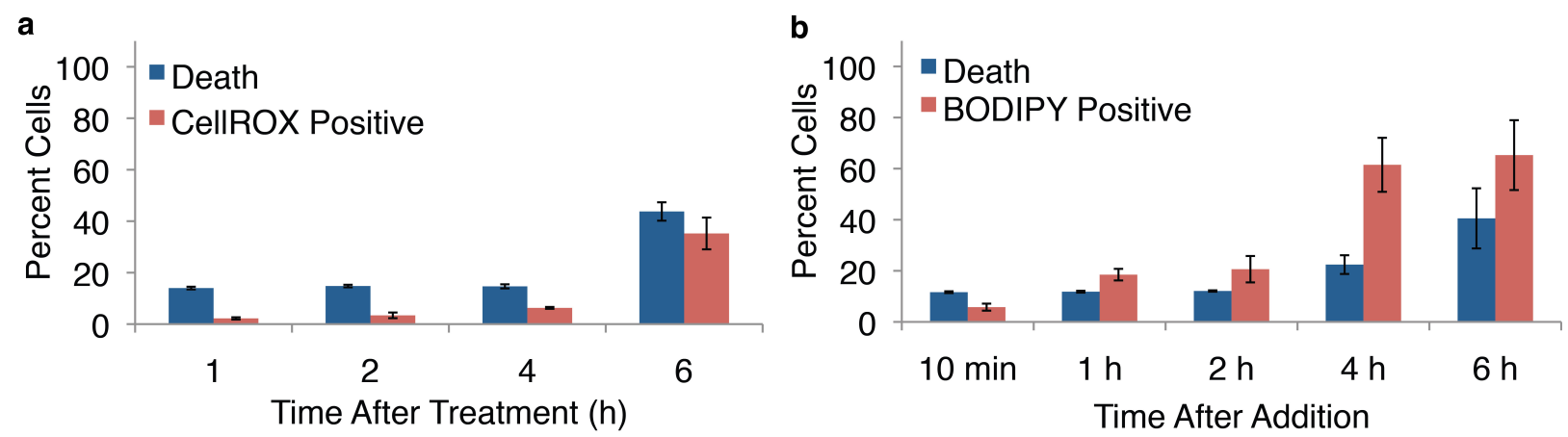

Supplementary Figure 9. A time-course experiment indicated $\mathrm{FINO}_{2}$ does not react directly with oxidation probes. a) Cells were treated with $7 \mu \mathrm{M}$ of $\mathrm{FINO}_{2}$ for indicated times and then the CellROX was added for $20 \mathrm{~min}$ following the appropriate protocol. b) Cells were treated with 6 $\mu \mathrm{M}$ of $\mathrm{FINO}_{2}$ and then the C11-BODIPY was added for 20 min following the appropriate protocol. These experiments verify there is no direct interaction between the redox probes and $\mathrm{FINO}_{2}$ because at each time point $\mathrm{FINO}_{2}$ was in contact with the probe for the same amount of time (20 min).

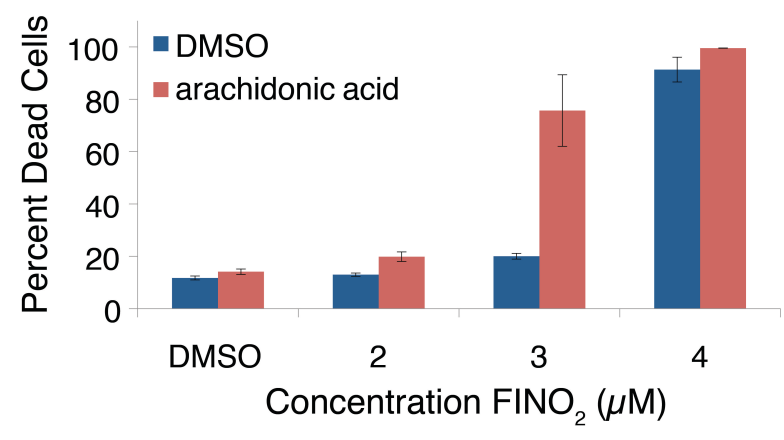

Supplementary Figure 10. Pretreatment of RS4;11 cells with $10 \mu \mathrm{M}$ of arachidonic acid for 2 hours caused increased cell death in response to $\mathrm{FINO}_{2}$. Percent dead cells indicate the Annexin $\mathrm{V}$ and 7AAD positive cell population. 


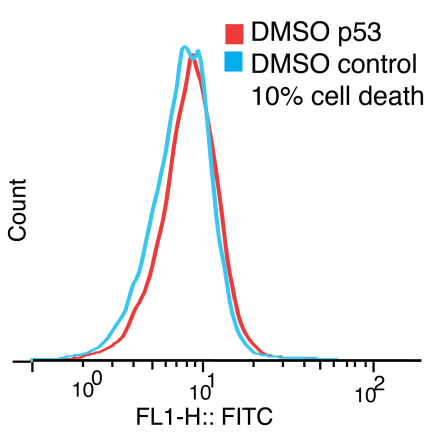

12 Hours

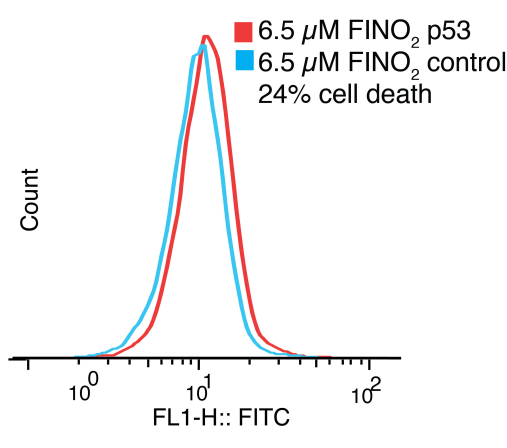

14 Hours

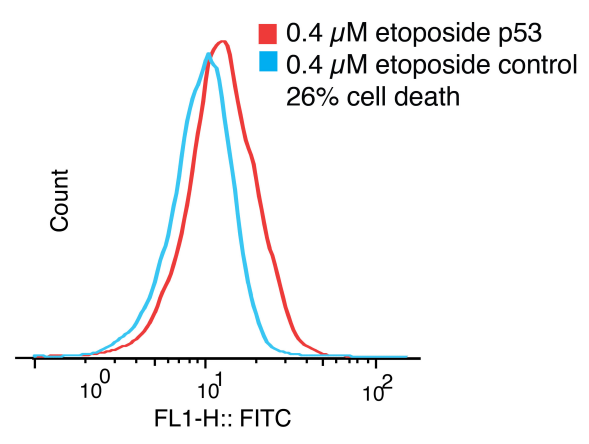

16 Hours

Supplementary Figure 11. In contrast to etoposide, $\mathrm{FINO}_{2}$ did not increase p53 protein expression even in cells expressing wild type p53 (RS4;11). (a) Expression of p53 is not increased by $\mathrm{FINO}_{2}$ treatment (middle) as it does with etoposide (right). A representative figure from at least three independent experiments is shown. Trypan Blue staining was used to indicate cell death.

a

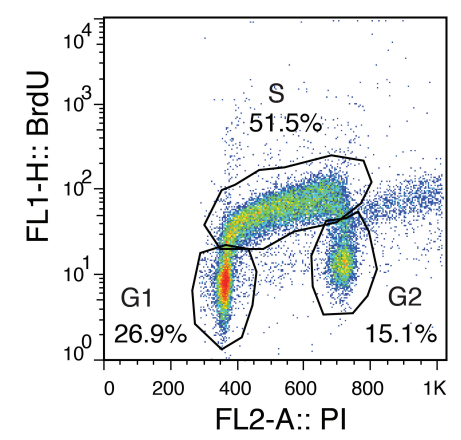

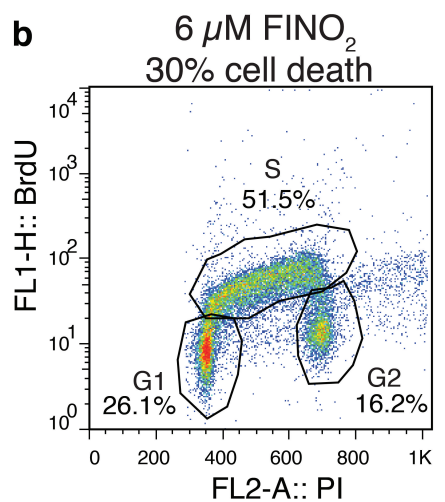

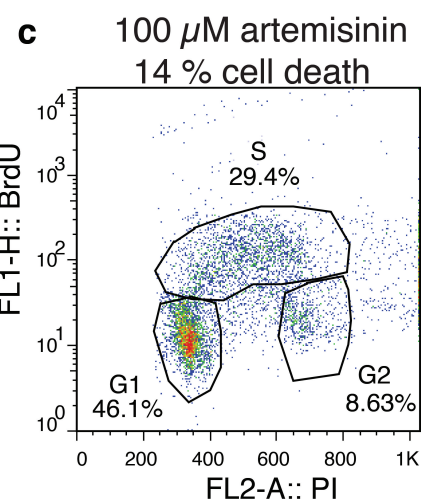

Supplementary Figure 12. Cell cycle analysis revealed no change in distribution upon treatment with $\mathrm{FINO}_{2}$. Cell cycle distribution was observed by monitoring bromodeoxyuridine (BrdU) incorporation and propidium iodide (PI) staining ${ }^{1}$. Trypan Blue staining was used to indicate cell death. A representative figure from at least three independent experiments is shown. 


\section{Supplementary Discussion}

The previously reported synthesis ${ }^{2}$ was optimized starting with one gram of ketone $\mathbf{1}$, which provided the protected bisperoxide 3 in $75 \%$ yield. ${ }^{3}$ Carrying forward one gram of protected bisperoxide 3, $\mathrm{FINO}_{2}$ was obtained in $67 \%$ yield. $^{2}$ This synthesis involves four linear steps (five total) from commercially available starting material, only two of which required purification, with an overall yield of pure $\mathrm{FINO}_{2}$ of about $50 \%$. This route provided quantities surpassing the amount needed for biological testing and allows for the production of gram quantities of $\mathrm{FINO}_{2}$.

To address potential stability concerns on the use of organic peroxides as drugs, $\mathrm{FINO}_{2}$ was subjected to thermogravimetric analysis. This method measures weight loss of a compound as a function of increasing temperature, and therefore gives information about a compound's stability. ${ }^{4}$ The precursor, bisperoxide 3, and $\mathrm{FINO}_{2}$ are both stable to over $150{ }^{\circ} \mathrm{C}$, suggesting that these compounds are more stable than might be anticipated for peroxide-containing structures. These temperatures are higher than would be required for the therapeutic use of these compounds and differ little in stability from artemisinin $\left(\mathrm{C}_{15} \mathrm{H}_{22} \mathrm{O}_{5}\right)$ and naproxen $\left(\mathrm{C}_{14} \mathrm{H}_{14} \mathrm{O}_{3}\right)$, which were chosen for comparison because they have similar numbers of carbon and oxygen atoms to $\mathrm{FINO}_{2}\left(\mathrm{C}_{15} \mathrm{H}_{28} \mathrm{O}_{3}\right)$. The thermal stability of $\mathrm{FINO}_{2}$ was corroborated by NMR analysis of a sample that had been heated to $150{ }^{\circ} \mathrm{C}$. 


\section{Materials and Methods}

\section{Cell Culture}

RS4;11 cells ${ }^{5}$ obtained from the American Type Culture Collection (ATCC) were grown in RPMI-1640 medium supplemented with 10\% fetal bovine serum (FBS) and 1\% penicillinstreptomycin under $5 \% \mathrm{CO}_{2}$ at $37^{\circ} \mathrm{C}$. BJ-5ta (BJ-hTERT) ${ }^{6,7}$ cells and $293 \mathrm{~T}^{8}$ cells obtained from the American Type Culture Collection (ATCC) were grown in DMEM medium supplemented with $10 \%$ fetal bovine serum (FBS) and $1 \%$ penicillin-streptomycin under $5 \% \mathrm{CO}_{2}$ at $37{ }^{\circ} \mathrm{C}$. BJELR $^{9}$ cells were generously donated by the laboratory of William Hahn at the Dana-Farber Cancer Institute and maintained under the same conditions as the BJ-5ta cells.

\section{Chemical Compounds}

The synthesis of $\mathrm{FINO}_{2}$ is described below. $\mathrm{FINO}_{2}$ was prepared as a $10 \mathrm{mM}$ stock solution in DMSO, aliquoted in single use portions, and frozen at $-20^{\circ} \mathrm{C}$ until the day of use. Serial dilutions of the $10 \mathrm{mM}$ stock into water were performed for use at the indicated concentrations. All other compounds were obtained from Sigma-Aldrich unless otherwise indicated. Etoposide was prepared as a $4 \mathrm{mM}$ stock solution in DMSO and serially diluted into water for use at the indicated concentrations.

\section{Thermogravimetric Analysis (TGA)}

The PerkinElmer Pyris ${ }^{\mathrm{TM}} 1$ TGA instrument and software were used to measure the thermal stability of various compounds under an atmosphere of nitrogen. A sample of 1-3 mg was heated from 30 to $300{ }^{\circ} \mathrm{C}$ at a rate of $10^{\circ} \mathrm{C} /$ minute for solid compounds and $1{ }^{\circ} \mathrm{C} /$ minute for oils. The weight was measured at one-second intervals. All data points were plotted and a line of best fit is 
displayed. All compounds were measured in at least two independent experiments with little variability observed between readings.

\section{Cell Viability Assay}

BJ-hTERT and BJ-ELR cells were plated at 33,000 cells per mL in a white 96-well plate and the plate was returned to the cell culture incubator for $24 \mathrm{~h}$. Either vehicle (DMSO in water) or indicated compound was added to achieve a 10-fold dilution by addition of $10 \mu \mathrm{L}$ of stock solution to $100 \mu \mathrm{L}$ of cells in media and the plate was returned to the cell culture incubator for the indicated times. The Promega CellTiter-Glo ${ }^{\circledR}$ Luminescence Assay was used as indicated in the manual, and luminescence was read on a FlexStation 3 Multi-Mode Microplate Reader. All percent viabilities reported are normalized to vehicle-treated cells. All experiments were performed in triplicate, and error bars reflect the standard deviation of one experiment. A representative graph of at least three independent experiments is shown.

\section{Expression Level of p53}

RS4;11 cells were plated at 666,000 cells per mL. Either vehicle (DMSO in water) or indicated compound was added to achieve a 10-fold dilution by addition of $100 \mu \mathrm{L}$ of stock solution to 1 $\mathrm{mL}$ of cells in media and the plate was returned to the cell culture incubator for $24 \mathrm{~h}$. Trypan Blue staining and counting using a hemocytometer determined the percentage of cell death in each sample. The cells were fixed and permeablized using the BD Cytofix/Cytoperm ${ }^{\mathrm{TM}}$ Fixation Permeabilization kit (554714). A fluorescein isothiocyanate (FITC)-conjugated p53 antibody or control antibody (FITC Mouse Anti-p53 Antibody Set, BD Pharmingen ${ }^{\mathrm{TM}}$ ) was incubated with the cells at a 1:50 dilution for 30 minutes on ice and in the dark. The samples were processed by 
flow cytometry on the BD FACSCalibur cell analyzer. Analysis was conducted using FlowJo (Tree Star, Inc.). Representative results of at least three independent experiments are shown.

\section{Annexin V-PE and 7-Aminoactinomycin D (7AAD) Apoptosis Assay}

RS4;11 cells were plated at 666,000 cells per mL. Either vehicle (DMSO in water) or indicated compound was added to achieve a 10 -fold dilution by addition of $50 \mu \mathrm{L}$ of stock solution to 500 $\mu \mathrm{L}$ of cells in media and the plate was returned to the cell culture incubator for the indicated times. The BD Pharmagen ${ }^{\mathrm{TM}}$ PE Annexin V Apoptosis Detection Kit protocol was followed. The cells were pelleted and washed with phosphate-buffered saline (PBS) prior to staining with annexin V-PE and 7AAD for 20 minutes in the dark. The samples were transferred to flow cytometry tubes and were processed on the BD FACSCalibur cell analyzer. Analysis was conducted using FlowJo (Tree Star, Inc.). All experiments were performed in triplicate, and error bars reflect the standard deviation of one experiment. A representative graph of at least three independent experiments is shown.

\section{Bcl-2 Overexpression}

pCDH-puro-Bcl2 was a gift from Jialiang Wang at Vanderbilt University Medical Center (Addgene plasmid \#46971) ${ }^{10}$. plenti-neo-GFP was a gift from the laboratory of Mark Phillips at New York University Langone Medical Center. The cDNA constructs were transfected into $293 \mathrm{~T}$ cells along with helper plasmids using the calcium phosphate method ${ }^{11,12}$ to produce replication-defective virus. The supernatant was collected $48 \mathrm{~h}$ after transfection and used to transduce RS4;11 cells supplemented with $8 \mathrm{mg} / \mathrm{mL}$ of Polybrene ${ }^{\circledR}$. The virus-containing medium was replaced after $24 \mathrm{~h}$. The Bcl-2 overexpressing cells and the GFP control cells were then selected for by treatment with $2 \mu \mathrm{g} / \mathrm{mL}$ of puromycin and $600 \mu \mathrm{g} / \mathrm{mL}$ of G418, respectively. 
Overexpression of Bcl-2 was confirmed by Western blot at the time of plating each experiment (Fig. S6). About one million cells were lysed in $100 \mu \mathrm{L}$ of $0.5 \% \mathrm{NP}-40$ lysis buffer also containing $50 \mathrm{mM}$ of Tris- $\mathrm{HCl}, 150 \mathrm{mM}$ of $\mathrm{NaCl}, 1 \mathrm{mM}$ of PMSF, $1 \mathrm{mM}$ of NaF, and protease inhibitor (GE Healthcare). The samples were incubated on ice for $15 \mathrm{~min}$. The lysates were centrifuged at $12,000 \mathrm{rpm}$ for $10 \mathrm{~min}$ at $4{ }^{\circ} \mathrm{C}$. The protein was quantified, then subjected to electrophoresis on $12 \%$ SDS-Tris acrylamide gels and transferred to PVDF membranes. The membranes were incubated with $4 \%$ milk in PBST ( $0.1 \%$ tween) for $1 \mathrm{~h}$ followed by incubation with a 1:750 dilution of mouse monoclonal antibody to Bcl-2 (Santa Cruz, sc-7382) or a 1:5000 dilution of rabbit polyclonal antibody to $\beta$-Tubulin (Abcam, ab6046) for $2 \mathrm{~h}$ at room temperature. The membranes were washed with PBST then incubated with a 1:10,000 dilution of horseradish peroxidase (HRP)-conjugated secondary antibody to mouse or rabbit (GE Healthcare) for $1 \mathrm{~h}$ and developed using enhanced chemiluminescence (ECL; GE Healthcare). The response of GFP and Bcl-2 overexpressing cells to treatment with either etoposide or $\mathrm{FINO}_{2}$ for $24 \mathrm{~h}$ was detected using the BD Pharmagen ${ }^{\text {TM }}$ PE Annexin V Apoptosis Detection Kit, as described above.

\section{Modulation of Cell Death with Chemical Compounds}

RS4;11 cells were plated at 666,000 cells per mL. Either vehicle or indicated compound was added to achieve the final desired concentration (listed below) and the plate was returned to the cell culture incubator for at least $2 \mathrm{~h}$. Either vehicle, $\mathrm{FINO}_{2}$, or etoposide (as a control) were then added to the give the indicated concentration and the plate was returned to the cell culture incubator for $24 \mathrm{~h}$. Cell death was detected using the BD Pharmagen ${ }^{\mathrm{TM}}$ PE Annexin V Apoptosis Detection Kit, as described above. Representative results of at least three independent experiments are shown. Compound concentrations: $2.4 \mu \mathrm{M}$ of caspase inhibitor z-VAD-FMK 
(BioVision); $20 \mu \mathrm{M}$ of deferoxamine (DFO); $38 \mu \mathrm{M}$ of ferric ammonium citrate (FAC); $500 \mathrm{nM}$ of Ferrostatin; $200 \mathrm{nM}$ of Liproxstatin (ChemDiv); $5 \mu \mathrm{M}$ of nordihydroguaiaretic acid (NDGA); $100 \mu \mathrm{M}$ of indomethacin; $10 \mu \mathrm{M}$ of arachidonic acid

\section{Cell Cycle Analysis}

RS4;11 cells were plated at 666,000 cells per mL. Either vehicle (DMSO in water) or indicated compound was added to achieve a 100 -fold dilution by addition of $30 \mu \mathrm{L}$ of stock solution to 3 $\mathrm{mL}$ of cells in media and the plate was returned to the cell culture incubator for $24 \mathrm{~h}$. Trypan Blue staining and counting using a hemocytometer determined the percentage of cell death in each sample. The cells were treated with $5 \mu \mathrm{g} / \mathrm{mL}$ of bromodeoxyuridine (BrdU) and the plate was returned to the cell culture incubator for $30 \mathrm{~min}$. The cells were then fixed using $1 \mathrm{~mL}$ of cold $70 \%$ ethanol/ water solution and incubated overnight at $4{ }^{\circ} \mathrm{C}$. After washing with PBS, the cells were resuspended in $200 \mu \mathrm{L}$ of $0.4 \mathrm{mg} / \mathrm{mL}$ pepsin in $0.1 \mathrm{M} \mathrm{HCl}$ (aq) and incubated at room temperature for $20 \mathrm{~min}$. The cells were centrifuged and resuspended in $0.5 \mathrm{~mL}$ of $2 \mathrm{M} \mathrm{HCl}$ and incubated at $37^{\circ} \mathrm{C}$ for $10 \mathrm{~min}$. The cells were centrifuged and resuspended in $1.5 \mathrm{~mL}$ of $0.05 \mathrm{M}$ of sodium borate $(\mathrm{pH} 8.5)$ and incubated for $5 \mathrm{~min}$ at room temperature. After washing twice with $0.1 \%$ bovine serum albumin (BSA) in PBS, the cells were resuspended in $50 \mu \mathrm{L}$ of a $1: 50$ dilution FITC-anti-BrdU (Rouche, 11202693001) in the dark at room temperature for $45 \mathrm{~min}$. After washing with $0.1 \%$ BSA in PBS, the cells were resuspended in a solution containing 200 $\mu \mathrm{L}$ of $0.1 \%$ BSA in PBS, $2 \mu \mathrm{L}$ of $100 \mathrm{mg} / \mathrm{mL}$ RNAse A, and $10 \mu \mathrm{L}$ of $1 \mathrm{mg} / \mathrm{mL}$ propidium iodide (PI) and incubated for $1 \mathrm{~h}$ at $37^{\circ} \mathrm{C}$ in the dark. After centrifugation, the cells were resuspended in $400 \mu \mathrm{L}$ of $0.1 \%$ BSA in PBS and transferred to flow cytometry tubes. The samples were processed on the BD FACSCalibur cell analyzer. Analysis was conducted using 
FlowJo (Tree Star, Inc.). Representative results of at least three independent experiments are shown.

\section{CellROX ${ }^{\circledR}$ Green Reagent and BODIPY 581/591 C11}

RS4;11 cells were plated at 666,000 cells per mL. Either vehicle (DMSO in water) or indicated compound was added to achieve a 10 -fold dilution by addition of $50 \mu \mathrm{L}$ of stock solution to 500 $\mu \mathrm{L}$ of cells in media and the plate was returned to the cell culture incubator for the indicated times. An aliquot of $1.1 \mu \mathrm{L}$ of a $2.5 \mathrm{mM}$ stock of either CellROX® Green Reagent (Life Technologies, C10444) or BODIPY 581/591 C11 dye (Life Technologies, D-3861) was added to the cells and the plate was returned to the cell culture incubator for $20 \mathrm{~min}$. After washing the cells with PBS twice, the cells were transferred to flow cytometry tubes and processed on the BD FACSCalibur cell analyzer. Analysis was conducted using FlowJo (Tree Star, Inc.).

Representative results of at least three independent experiments are shown.

\section{BioVision MitoCapture ${ }^{\mathrm{TM}}$ Mitochondrial Apoptosis Detection Kit}

RS4;11 cells were plated at 666,000 cells per mL. Either vehicle (DMSO in water) or indicated compound was added to achieve a 100 -fold dilution by addition of $30 \mu \mathrm{L}$ of stock solution to 3 $\mathrm{mL}$ of cells in media and the plate was returned to the cell culture incubator for $24 \mathrm{~h}$. Trypan Blue staining and counting using a hemocytometer determined the percentage of cell death in each sample. The BioVision MitoCapture ${ }^{\mathrm{TM}}$ Mitochondrial Apoptosis Detection Kit protocol was followed using one million live cells per sample. Samples were processed on the BD FACSCalibur cell analyzer. Analysis was conducted using FlowJo (Tree Star, Inc.). Representative results of at least three independent experiments are shown. 


\section{Caspase Western Blots}

Trypan Blue staining and counting using a hemocytometer determined the percentage of cell death in each sample. About one million cells were lysed in $100 \mu \mathrm{L}$ of $0.5 \%$ NP-40 lysis buffer also containing 50 of $\mathrm{mM}$ Tris- $\mathrm{HCl}, 150$ of $\mathrm{mM} \mathrm{NaCl}, 1 \mathrm{mM}$ of PMSF, $1 \mathrm{mM}$ of $\mathrm{NaF}$, and protease inhibitor (GE Healthcare). The samples were incubated on ice for $15 \mathrm{~min}$. The lysates were centrifuged at $12,000 \mathrm{rpm}$ for $10 \mathrm{~min}$ at $4{ }^{\circ} \mathrm{C}$. The protein was quantified, then subjected to electrophoresis on 9\% SDS-Tris acrylamide gels and transferred to PVDF membranes. The membranes were incubated with $4 \%$ milk in PBST $(0.1 \%$ tween $)$ for $1 \mathrm{~h}$, followed by incubation with a 1:500 dilution of rabbit polyclonal antibody to cleaved caspase-7 (Cell Signaling, 9491), cleaved caspase-6 (Cell Signaling, 9761), cleaved caspase-3 (Cell Signaling, 9661), or 1:5000 dilution of rabbit polyclonal antibody to $\beta$-Tubulin (Abcam, ab6046) overnight at $4{ }^{\circ} \mathrm{C}$. The membranes were washed with PBST then incubated with a 1:10,000 dilution of horseradish peroxidase (HRP)-conjugated secondary antibody to mouse or rabbit (GE Healthcare) for $1 \mathrm{~h}$ and developed using enhanced chemiluminescence (ECL; GE Healthcare). Representative blots of three independent experiments are shown (Supplementary Figure 6).

\section{Electron Microscopy}

RS4;11 cells were plated at 666,000 cells per mL. Either vehicle (DMSO in water) or $\mathrm{FINO}_{2}$ was added to achieve a 10-fold dilution by addition of $800 \mu \mathrm{L}$ of stock solution to $8 \mathrm{~mL}$ of cells in media and the plate was returned to the cell culture incubator for nine, ten, eleven, twelve, or thirteen hours. Trypan Blue staining and counting using a hemocytometer determined the percentage of cell death in each sample. The eleven $\mathrm{h}$ time point exhibiting $22 \%$ cell death was chosen for analysis. Cells were submitted to the Microscopy Core at New York University 
Langone Medical Center for processing and acquisition of transmission electron microscopy images. 


\section{General Synthesis Procedures}

Using Bruker AV-400, AV-500, or AVIII-600 spectrometers at ambient temperature, ${ }^{1} \mathrm{H}$ NMR spectra were recorded at 400,500 , or $600 \mathrm{MHz}$, respectively and ${ }^{13} \mathrm{C}$ NMR spectra were recorded at 100,125 , or $150 \mathrm{MHz}$, respectively. Chemical shifts are reported in ppm on the $\delta$ scale, referenced to internal standard tetramethylsilane $(\delta 0.00)$ or residual solvent $\left({ }^{1} \mathrm{H}\right.$ NMR: $\delta$ 7.26 for $\mathrm{CDCl}_{3}$ or 7.16 for $\mathrm{C}_{6} \mathrm{D}_{6} ;{ }^{13} \mathrm{C}$ NMR: $\delta 77.2$ for $\mathrm{CDCl}_{3}$ or 128.1 for $\left.\mathrm{C}_{6} \mathrm{D}_{6}\right) \cdot{ }^{13}$ Infrared (IR) spectra were obtained by a Thermo Nicolet AVATAR 360 Fourier Transform Infrared Spectrometer using attenuated total reflectance (ATR). High-resolution mass spectra (HRMS) were aquired on an Agilent 6224 Accurate-Mass time-of-flight spectrometer using peak matching. Analytical thin layer chromatography was performed with Silicycle silica gel $60 \AA$ $\mathrm{F}_{254}$ plates. Flash chromatography was perfomed using the indicated solvent system on Silicycle silica gel $\left(\mathrm{SiO}_{2}\right) 60$ (230-400 mesh). Tetrahydrofuran (THF), methylene chloride $\left(\mathrm{CH}_{2} \mathrm{Cl}_{2}\right)$, diethyl ether $\left(\mathrm{Et}_{2} \mathrm{O}\right)$, ethyl acetate (EtOAc) and $N, N$-dimethylformamide (DMF) were dried by filtration through alumina. ${ }^{14}$ All dry reactions were run under an atmosphere of either argon or nitrogen in flame-dried glassware.

Caution: In general, hydrogen peroxide and organic peroxides should be handled with care. Avoid exposure to strong heat, light, mechanical shock, oxidizable organic materials, and metals. All reactions should be carried out behind a blast shield. ${ }^{15}$ 


\section{Synthesis of $\mathrm{FINO}_{2}$}

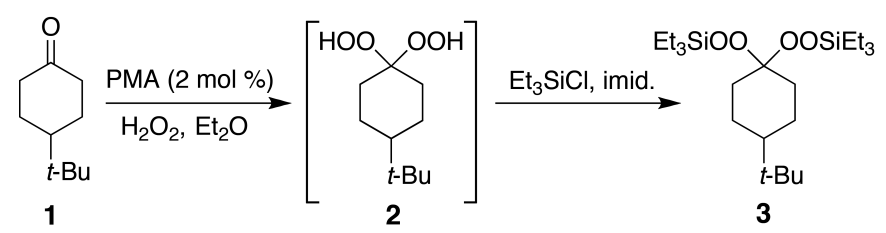

Silylated Peroxyketal 3. 1,1-Dihydroperoxide 2 was prepared following a literature procedure. ${ }^{3}$ Ethereal hydrogen peroxide was prepared (behind a blast shield) by addition of sodium chloride ( $\mathrm{NaCl}$, until the solution becomes saturated) to $\mathrm{H}_{2} \mathrm{O}_{2}(30 \%$ aqueous solution, $90 \mathrm{~mL})$. Diethyl ether $\left(\mathrm{Et}_{2} \mathrm{O}, 40 \mathrm{~mL}\right)$ was placed in a separatory funnel and it was washed with the salt-saturated aqueous peroxide solution $(15 \mathrm{~mL} \times 6)$. The ethereal layer was dried over magnesium sulfate $\left(\mathrm{MgSO}_{4}\right)$ and filtered directly into a flame-dried round-bottom flask. Ketone 1 (1.00 g, 6.49 mmol) and phosphomolybdic acid hydrate (PMA, $0.237 \mathrm{~g}, 0.120 \mathrm{mmol}$ ) were added to the ethereal peroxide solution. After $3 \mathrm{~h}$ at ambient temperature, diethyl ether $\left(\mathrm{Et}_{2} \mathrm{O}, 25 \mathrm{~mL}\right)$ and $\mathrm{H}_{2} \mathrm{O}(50 \mathrm{~mL})$ were added. The mixture was added to $\mathrm{Et}_{2} \mathrm{O}(25 \mathrm{~mL})$ and the layers were separated. The aqueous layer was extracted with $\mathrm{Et}_{2} \mathrm{O}(3 \times 40 \mathrm{~mL})$. The organic layers were combined, dried over $\mathrm{MgSO}_{4}$, filtered, and concentrated under a stream of nitrogen. The unpurified product 2 exhibited spectroscopic properties consistent with those reported ${ }^{3}:{ }^{1} \mathrm{H}$ NMR $\left(500 \mathrm{MHz}, \mathrm{CDCl}_{3}\right) \delta 8.51(\mathrm{~s}, 1 \mathrm{H}), 7.70(\mathrm{~s}, 1 \mathrm{H}), 2.32-2.28(\mathrm{~m}, 2 \mathrm{H}), 1.73-1.71(\mathrm{~m}, 2 \mathrm{H}), 1.48-1.41$ (m, 2H), 1.29-1.21 (m, 2H), 1.09-1.03 (m, 1H), $0.87(\mathrm{~s}, 9 \mathrm{H})$.

The unpurified peroxide 2 was subjected to protection conditions ${ }^{2}$ by immediate dissolution into anhydrous THF $(10 \mathrm{~mL})$. Imidazole $(1.33 \mathrm{~g}, 19.5 \mathrm{mmol})$ was added followed by drop-wise addition over $30 \mathrm{~min}$ of freshly distilled triethylchlorosilane $(3.30 \mathrm{~mL}, 19.5 \mathrm{mmol})$. After $72 \mathrm{~h}$ at ambient temperature, a saturated aqueous solution of sodium bicarbonate $(35 \mathrm{~mL})$ was added to the reaction mixture. The reaction mixture was then added to hexanes $(50 \mathrm{~mL})$ and 
$\mathrm{H}_{2} \mathrm{O}(15 \mathrm{~mL})$. The layers were separated and the aqueous layer was extracted with hexanes (50 $\mathrm{mL}$ ). The organic layers were combined and washed with a saturated aqueous solution of sodium chloride $(50 \mathrm{~mL})$. The layers were separated and the aqueous layer was extracted with hexanes $(3 \times 75 \mathrm{~mL})$. The organic layers were combined, dried over $\mathrm{MgSO}_{4}$, filtered, and concentrated under reduced pressure. Purification by flash column chromatography $(100 \%$ hexanes) on Davisil ${ }^{\circledR}$ grade silica afforded triethylsilylperoxyketal 3 as a clear oil $(2.09 \mathrm{~g}, 75 \%)$, whose spectroscopic data matched those reported ${ }^{2}:{ }^{1} \mathrm{H}$ NMR $\left(400 \mathrm{MHz}, \mathrm{C}_{6} \mathrm{D}_{6}\right) \delta 2.61-2.59(\mathrm{~m}$, 2H), 1.57-1.56 (m, 2H), 1.40-1.38 (m, 4H), $1.15(\mathrm{t}, J=8.0 \mathrm{~Hz}, 9 \mathrm{H}), 1.11(\mathrm{t}, J=8.0 \mathrm{~Hz}, 9 \mathrm{H})$, $0.87(\mathrm{~m}, 1 \mathrm{H}), 0.86(\mathrm{q}, J=8.0 \mathrm{~Hz}, 6 \mathrm{H}), 0.82(\mathrm{~s}, 9 \mathrm{H}), 0.81(\mathrm{q}, J=8.0 \mathrm{~Hz}, 6 \mathrm{H}) ;{ }^{13} \mathrm{C}$ NMR $(100$ $\left.\mathrm{MHz}, \mathrm{C}_{6} \mathrm{D}_{6}\right) \delta 109.7,47.8,32.4,31.1,27.8,24.1,7.23,7.22,4.51,4.47$.

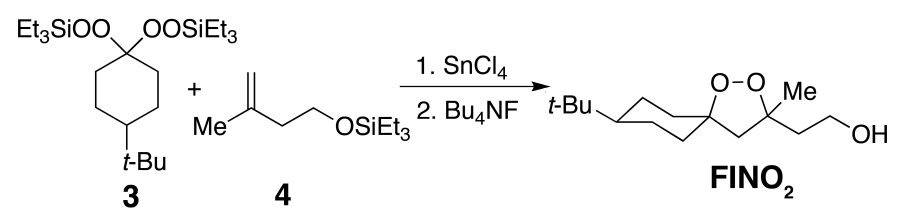

FINO $_{2}$. The synthesis of IINO $_{2}$ followed a general procedure reported previously. ${ }^{2}$ To a mixture of triethylsilylperoxyketal 3 (1.00 g, $2.31 \mathrm{mmol})$, triethyl(3-methylbut-3-enyloxy)silane $4^{16}$ (1.39 g, $6.93 \mathrm{mmol})$, and $\mathrm{CH}_{2} \mathrm{Cl}_{2}(14.4 \mathrm{~mL})$ was added $\mathrm{SnCl}_{4}(4.62 \mathrm{~mL})$ dropwise over $30 \mathrm{~min}$ at $-78^{\circ} \mathrm{C}$. The reaction mixture was stirred at $-10{ }^{\circ} \mathrm{C}$ for $12 \mathrm{~h}$, then was warmed to $-2{ }^{\circ} \mathrm{C}$. Cold $\mathrm{H}_{2} \mathrm{O}\left(0^{\circ} \mathrm{C}, 10 \mathrm{~mL}\right)$ was added to the reaction mixture. Potassium sodium tartrate tetrahydrate was added until the solution was saturated, and the mixture was stirred for $30 \mathrm{~min}$. The reaction mixture was partitioned between $\mathrm{Et}_{2} \mathrm{O}(70 \mathrm{~mL})$ and a saturated aqueous solution of sodium chloride $(70 \mathrm{~mL})$. The layers were separated and the aqueous layer was extracted with $\mathrm{Et}_{2} \mathrm{O}(3 \mathrm{x}$ $75 \mathrm{~mL}$ ). The organic layers were combined, dried over $\mathrm{MgSO}_{4}$, filtered, and concentrated under reduced pressure. The unpurified products were subjected immediately to deprotection 
conditions ${ }^{17}$ by dissolution into anhydrous THF $(23.0 \mathrm{~mL})$ followed by addition of tetrabutylammonium fluoride ( $1 \mathrm{M}$ solution in THF, $3.47 \mathrm{~mL}, 3 \mathrm{mmol})$. After $17 \mathrm{~h}$ at ambient temperature, the reaction mixture was partitioned between a saturated aqueous solution of sodium chloride $(60 \mathrm{~mL})$ and $\mathrm{Et}_{2} \mathrm{O}(60 \mathrm{~mL})$. The layers were separated and the organic layer was washed with a saturated aqueous solution of sodium chloride $(60 \mathrm{~mL})$. The aqueous layers were combined and extracted with $\mathrm{Et}_{2} \mathrm{O}(3 \times 75 \mathrm{~mL})$. The organic extracts were combined, dried over $\mathrm{MgSO}_{4}$, filtered, and concentrated under reduced pressure. Purification by flash column chromatography (12-25\% EtOAc in hexanes) afforded $\mathbf{F I N O}_{2}$ as a white solid $(0.396 \mathrm{~g}, 67 \%)$, whose spectroscopic data matched those reported ${ }^{2}$ : mp 79-81 ${ }^{\circ} \mathrm{C}$, lit $69-71{ }^{\circ} \mathrm{C} ;{ }^{1} \mathrm{H}$ NMR $(600$ $\left.\mathrm{MHz}, \mathrm{CDCl}_{3}\right) \delta 3.81-3.78(\mathrm{~m}, 2 \mathrm{H}), 2.24-2.22(\mathrm{~d}, J=12.0 \mathrm{~Hz}, 1 \mathrm{H}), 2.12-2.09(\mathrm{~m}, 3 \mathrm{H}), 2.05-$ $2.00(\mathrm{~m}, 2 \mathrm{H}), 1.83-1.80(\mathrm{~m}, 1 \mathrm{H}), 1.63-1.60(\mathrm{~m}, 2 \mathrm{H}), 1.48-1.46(\mathrm{~m}, 1 \mathrm{H}), 1.39-1.27(\mathrm{~m}, 3 \mathrm{H})$, $1.38(\mathrm{~s}, 3 \mathrm{H}), 0.98-0.94(\mathrm{~m}, 1 \mathrm{H}), 0.84(\mathrm{~s}, 9 \mathrm{H}) ;{ }^{13} \mathrm{C} \mathrm{NMR}\left(100 \mathrm{MHz}, \mathrm{CDCl}_{3}\right) \delta 85.5,84.9,59.5$, $57.7,47.2,41.6,36.2,35.8,32.5,27.6,24.5,24.0,23.8$.

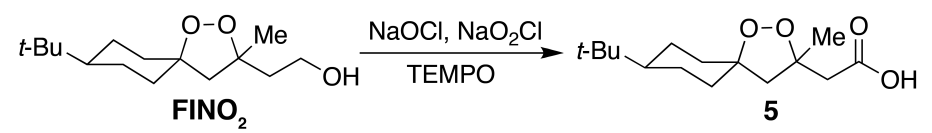

1,2-Dioxolane 5. A slightly modified literature procedure for oxidation of alcohols to carboxylic $\operatorname{acids}^{18}$ was followed to afford $\mathbf{5}$. A solution of $\mathbf{F I N O}_{2}(0.18 \mathrm{~g}, 0.70 \mathrm{mmol})$, 2,2,6,6-tetramethyl1-piperidinyloxy (TEMPO, $0.0077 \mathrm{mg}, 0.049 \mathrm{mmol}), \mathrm{CH}_{3} \mathrm{CN}(3.5 \mathrm{~mL})$, and aqueous phosphate buffer ( $\mathrm{pH} 6.7,2.6 \mathrm{~mL}$ ) was heated to $35^{\circ} \mathrm{C}$. Sodium chlorite (2.0 M aqueous solution, $\left.140 \mu \mathrm{L}\right)$ and sodium hypochlorite $(0.045 \mathrm{M}$ aqueous solution, $62 \mu \mathrm{L})$ were added simultaneously to the reaction mixture. After $30 \mathrm{~min}$, additional sodium chlorite $(2.0 \mathrm{M}$ aqueous solution, $560 \mu \mathrm{L})$ and sodium hypochlorite $(0.045 \mathrm{M}$ aqueous solution, $248 \mu \mathrm{L})$ were added. After 24 hours, more sodium chlorite (2.0 M aqueous solution, $180 \mu \mathrm{L})$, sodium hypochlorite $(0.045 \mathrm{M}$ aqueous 
solution, $25 \mu \mathrm{L})$ and TEMPO $(0.0015 \mathrm{mg}, 9.6 \mu \mathrm{mol})$ were added. After an additional 24 hours, the temperature was increased to $43{ }^{\circ} \mathrm{C}$. After $4 \mathrm{~h}$ at $43{ }^{\circ} \mathrm{C}$, the reaction mixture was allowed to cool to room temperature and $\mathrm{H}_{2} \mathrm{O}(10 \mathrm{~mL})$ was added. The reaction mixture was added to a mixture of $\mathrm{H}_{2} \mathrm{O}(20 \mathrm{~mL})$, an aqueous solution of saturated sodium chloride $(5 \mathrm{~mL})$, and $\mathrm{CH}_{2} \mathrm{Cl}_{2}$ $(30 \mathrm{~mL})$. The layers were separated and the aqueous layer was extracted with $\mathrm{CH}_{2} \mathrm{Cl}_{2}(3 \times 30$ $\mathrm{mL})$. Purification by flash column chromatography (20\% EtOAc/hexanes) on silica gel that had been pretreated with acetic acid ( $0.5 \%$ acetic acid/hexanes) afforded 1,2-dioxolane 5 as a white solid $(0.17 \mathrm{~g}, 91 \%)$ whose spectroscopic data matched those reported ${ }^{2}: \mathrm{mp} 134-137^{\circ} \mathrm{C}$, lit $113-$ $114{ }^{\circ} \mathrm{C} ;{ }^{1} \mathrm{H}$ NMR $\left(600 \mathrm{MHz}, \mathrm{CDCl}_{3}\right) \delta 2.78-2.72(\mathrm{dd}, J=22.8,15.0 \mathrm{~Hz}, 2 \mathrm{H}), 2.41-2.39(\mathrm{~d}, J=$ $12.6 \mathrm{~Hz}, 1 \mathrm{H}), 2.15-2.12(\mathrm{~m}, 2 \mathrm{H}), 1.96-1.93(\mathrm{~m}, 1 \mathrm{H}), 1.62-1.60(\mathrm{~m}, 2 \mathrm{H}), 1.57-1.52$ (td, $13.8,4.2$ $\mathrm{Hz}, 1 \mathrm{H}), 1.47(\mathrm{~s}, 3 \mathrm{H}), 1.37-1.32(\mathrm{~m}, 2 \mathrm{H}), 1.25-1.21(\mathrm{~m}, 1 \mathrm{H}), 0.98-0.94(\mathrm{~m}, 1 \mathrm{H}), 0.84(\mathrm{~s}, 9 \mathrm{H})$;

${ }^{13} \mathrm{C}$ NMR $\left(150 \mathrm{MHz}, \mathrm{CDCl}_{3}\right) \delta 176.5,84.9,83.1,56.5,46.9,44.0,35.9,35.6,32.3,27.4,23.9$, 23.7, 23.4.

\section{Preparation of Enantiomers of $\mathrm{FINO}_{2}$ Using a Chiral Auxiliary}

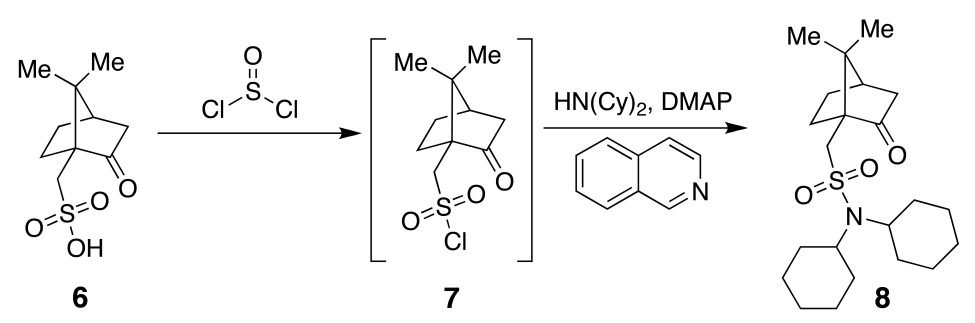

Sulfonamide 8. Sulfonyl chloride 7 was prepared following a literature procedure. ${ }^{19}$ Freshly distilled thionyl chloride was added by syringe to $(1 S)-(+)-10$-Camphorsulfonic acid that had been recrystallized from ethyl acetate (EtOAc). The reaction mixture was heated to $110^{\circ} \mathrm{C}$ for 3 h. After the reaction mixture was cooled to room temperature, $5 \mathrm{~mL}$ of dry toluene was added, and the mixture was concentrated under reduced pressure. An additional $5 \mathrm{~mL}$ of dry toluene was 
added, and the mixture was concentrated again. The spectroscopic data of sulfonyl chloride 7 matched the data reported ${ }^{19}:{ }^{1} \mathrm{H}$ NMR $\left(600 \mathrm{MHz}, \mathrm{CDCl}_{3}\right) \delta 4.32-4.30(\mathrm{~d}, J=14.6 \mathrm{~Hz}, 1 \mathrm{H})$, 3.74-3.71 (d, $J=14.6 \mathrm{~Hz}, 1 \mathrm{H}), 2.50-2.42(\mathrm{~m}, 2 \mathrm{H}), 2.17-2.16(\mathrm{~m}, 1 \mathrm{H}), 2.12-2.07(\mathrm{~m}, 1 \mathrm{H}), 2.01-$ $1.98(\mathrm{~d}, J=18.7 \mathrm{~Hz}, 1 \mathrm{H}), 1.80-1.75(\mathrm{~m}, 1 \mathrm{H}), 1.53-1.47$ (m, $1 \mathrm{H}), 1.15(\mathrm{~s}, 3 \mathrm{H}), 0.93(\mathrm{~s}, 3 \mathrm{H}) ;{ }^{13} \mathrm{C}$ NMR (150 MHz, $\left.\mathrm{CDCl}_{3}\right) \delta 212.8,64.3,59.7,48.2,42.8,42.3,26.9,25.3,19.8,19.7$.

The unpurified sulfonyl chloride 7 was immediately subjected to previously described conditions to form sulfonamide $\mathbf{8} .{ }^{20}$ The sulfonyl chloride was dissolved in $\mathrm{N}, \mathrm{N}$ dimethylformamide (DMF, $1 \mathrm{M}, 25 \mathrm{~mL}$ ) and cooled to $0{ }^{\circ} \mathrm{C}$. In another flame-dried flask, 4(dimethylamino)pyridine (0.608 g, $4.98 \mathrm{mmol})$, isoquinoline $(5.77 \mathrm{~mL}, 49.8 \mathrm{mmol})$, and dicyclohexylamine $(9.9 \mathrm{~mL}, 49.8 \mathrm{mmol})$ were dissolved in DMF $(25 \mathrm{~mL})$ and cooled to $0{ }^{\circ} \mathrm{C}$. The sulfonyl chloride solution was added by syringe pump over $2 \mathrm{~h}$ to the solution of amines. After $4 \mathrm{~h}$ of stirring at $0{ }^{\circ} \mathrm{C}, 50 \mathrm{~mL}$ of $10 \%$ citric acid in water were added. The resulting precipitate was filtered and washed with $\mathrm{CH}_{2} \mathrm{Cl}_{2}$ until the precipitate was white in color. The precipitate was dissolved in $50 \mathrm{~mL}$ of $\mathrm{CH}_{2} \mathrm{Cl}_{2}$ and washed with water $(50 \mathrm{~mL})$. The aqueous layer was extracted with $\mathrm{CH}_{2} \mathrm{Cl}_{2}(3 \times 50 \mathrm{~mL})$. The organic extracts were combined, dried over $\mathrm{MgSO}_{4}$, filtered, and concentrated under reduced pressure. Purification by flash column chromatography (12.5\% EtOAc in hexanes) afforded sulfonamide 8 (5.64 g, 57\%), whose spectroscopic data matched those reported ${ }^{20}$ : mp $130-132{ }^{\circ} \mathrm{C}$, lit $134-135^{\circ} \mathrm{C} ;{ }^{1} \mathrm{H}$ NMR $(600$ $\left.\mathrm{MHz}, \mathrm{CDCl}_{3}\right) \delta 3.33-3.30(\mathrm{~d}, J=14.5 \mathrm{~Hz}, 1 \mathrm{H}), 2.81-2.78(\mathrm{~d}, J=14.5 \mathrm{~Hz}, 1 \mathrm{H}), 2.62-2.58(\mathrm{~m}$, 1H), 2.39-2.35 (m, 1H), 2.09-2.07 (m, 1H), 2.05-2.01 (m, 1H), 1.93 (s, 1H), 1.90 (s, 1H), 1.81$1.78(\mathrm{~m}, 12 \mathrm{H}), 1.63-1.59(\mathrm{~m}, 3 \mathrm{H}), 1.42-1.38(\mathrm{~m}, 1 \mathrm{H}), 1.37-1.30(\mathrm{~m}, 4 \mathrm{H}), 1.17(\mathrm{~s}, 3 \mathrm{H}), 1.17-$ $1.13(\mathrm{~m}, 3 \mathrm{H}), 0.89(\mathrm{~s}, 3 \mathrm{H}) ;{ }^{13} \mathrm{C} \mathrm{NMR}\left(150 \mathrm{MHz}, \mathrm{CDCl}_{3}\right) \delta 215.5,59.0,57.6,52.2,47.4,42.9$, 
42.5, 32.9, 32.5, 26.8, 26.44, 26.43, 25.3, 25.2, 20.3, 19.8; HRMS (TOF MS ES+) $m / z$ calcd for $\mathrm{C}_{22} \mathrm{H}_{37} \mathrm{NNaO}_{3} \mathrm{~S}(\mathrm{M}+\mathrm{Na})^{+} 418.2386$, found 418.2396; $[\alpha]_{\mathrm{D}}^{23}+29\left(c 0.41, \mathrm{CHCl}_{3}\right)$.
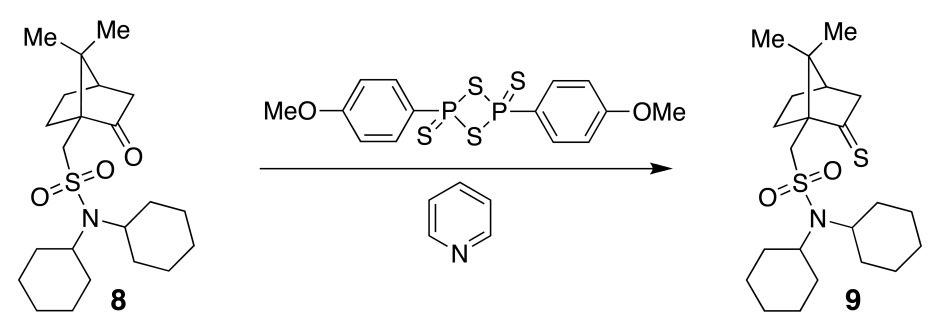

Thione 9. Thione 9 was prepared following a literature procedure. ${ }^{21}$ Lawesson's reagent was recrystallized from toluene, and pyridine was dried over molecular sieves prior to use. A solution of sulfonamide 8 (1.22 g, $3.08 \mathrm{mmol})$, Lawesson's reagent (1.51 g, $3.72 \mathrm{mmol})$, and toluene $(4.85 \mathrm{~mL})$ were heated to $130^{\circ} \mathrm{C}$. After the solution started to reflux, pyridine $(126 \mu \mathrm{L}, 1.57$ mmol) was added by syringe. After $19 \mathrm{~h}$, aqueous sodium bicarbonate $(5 \mathrm{~mL})$ was added to the reaction mixture. The reaction mixture was partitioned between aqueous sodium bicarbonate (40 $\mathrm{mL})$ and $\mathrm{Et}_{2} \mathrm{O}(40 \mathrm{~mL})$. The organic layer was washed with brine $(40 \mathrm{~mL})$. The combined aqueous layers were combined and extracted with $\mathrm{Et}_{2} \mathrm{O}(3 \times 50 \mathrm{~mL})$. The organic extracts were combined, dried over $\mathrm{MgSO}_{4}$, filtered, and concentrated under reduced pressure. Purification by flash column chromatography (7\% EtOAc in hexanes) afforded thione 9 as an orange solid $(0.478 \mathrm{~g}, 38 \%)$ whose spectroscopic data matched those reported ${ }^{21}: \mathrm{mp} 155-157^{\circ} \mathrm{C}$, lit $145-150$ ${ }^{\circ} \mathrm{C} ;{ }^{1} \mathrm{H}$ NMR (400 MHz, $\left.\mathrm{CDCl}_{3}\right)$ 8 3.91-3.87 (d, $\left.J=14.6 \mathrm{~Hz}, 1 \mathrm{H}\right), 3.35-3.32(\mathrm{~m}, 2 \mathrm{H}), 2.92-2.89$ $(\mathrm{d}, J=14.6 \mathrm{~Hz}, 1 \mathrm{H}), 2.81-2.67(\mathrm{~m}, 2 \mathrm{H}), 2.50-2.45(\mathrm{~d}, J=20.8 \mathrm{~Hz}, 1 \mathrm{H}), 2.15-2.13(\mathrm{~m}, 1 \mathrm{H})$, 2.10-2.08 (m, 1H), 1.85-1.75 (m, 12H), 1.65-1.61 (m, 2H), 1.55-1.42 (m, 2H), 1.35-1.30 (m, 3H), $1.24(\mathrm{~s}, 3 \mathrm{H}), 1.17-1.08(\mathrm{~m}, 2 \mathrm{H}), 1.07-0.95(\mathrm{~m}, 1 \mathrm{H}), 0.85(\mathrm{~s}, 3 \mathrm{H}) ;{ }^{13} \mathrm{C}$ NMR (150 MHz, $\left.\mathrm{CDCl}_{3}\right) \delta 265.9,69.9,57.6,54.91,54.88,49.8,45.0,33.1,32.5,29.7,27.0,26.5,25.2,20.5,19.8$ 
HRMS (TOF MS ES + ) $m / z$ calcd for $\mathrm{C}_{22} \mathrm{H}_{37} \mathrm{NNaO}_{3} \mathrm{~S}(\mathrm{M}+\mathrm{Na})^{+} 434.2163$, found 434.2158;

$[\alpha]_{\mathrm{D}}^{23}+147\left(c 1.03, \mathrm{CHCl}_{3}\right)$.

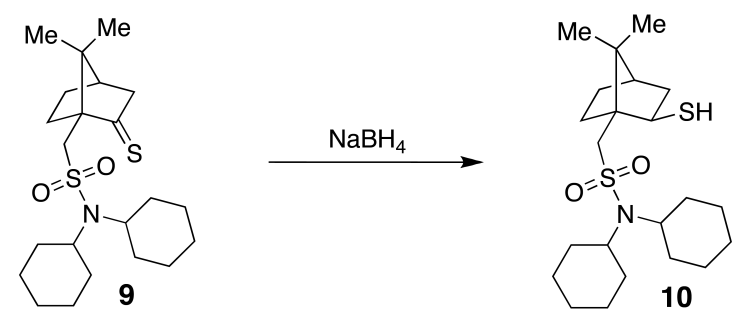

Thiol 10. Thiol 10 was prepared following a literature procedure. ${ }^{21}$ To a cold $\left(0{ }^{\circ} \mathrm{C}\right)$ solution of thione $9(0.150 \mathrm{~g}, 0.364 \mathrm{mmol})$, tetrahydrofuran $(1.79 \mathrm{~mL}, 0.204 \mathrm{M})$, and isopropanol $(1.79 \mathrm{~mL}$, $0.204 \mathrm{M})$ was added sodium borohydride $(0.138 \mathrm{~g}, 3.64 \mathrm{mmol})$. The reaction mixture was stirred at $0{ }^{\circ} \mathrm{C}$ for 20 minutes before warming to room temperature for an additional 30 minutes. Excess sodium borohydride was quenched by drop-wise addition of $1 \mathrm{M} \mathrm{HCl}$ (aq) until bubbling stopped. The reaction mixture was partitioned between brine $(30 \mathrm{~mL})$ and $\mathrm{Et}_{2} \mathrm{O}(35 \mathrm{~mL})$. The aqueous layer was extracted with $\mathrm{Et}_{2} \mathrm{O}(3 \times 40 \mathrm{~mL})$. The organic extracts were combined, dried over $\mathrm{MgSO}_{4}$, filtered, and concentrated under reduced pressure. Purification by flash column chromatography (4\% EtOAc in hexanes) afforded thiol 10 as a white solid $(0.1417 \mathrm{~g}, 94 \%)$ whose spectroscopic data matched those reported ${ }^{21}$ : mp $122-125{ }^{\circ} \mathrm{C}$, lit $105-110{ }^{\circ} \mathrm{C} ;{ }^{1} \mathrm{H}$ NMR (400 MHz, $\left.\mathrm{CDCl}_{3}\right) \delta 3.74-3.71(\mathrm{~d}, J=13.4 \mathrm{~Hz}, 1 \mathrm{H}), 3.47-3.43(\mathrm{~m}, 1 \mathrm{H}), 3.33-3.31(\mathrm{~m}, 2 \mathrm{H})$, $2.73-2.71(\mathrm{~d}, J=13.4 \mathrm{~Hz}, 1 \mathrm{H}), 2.57-2.56(\mathrm{~d}, J=7.5 \mathrm{~Hz}, 1 \mathrm{H}), 2.12-2.07(\mathrm{~m}, 1 \mathrm{H}), 2.01-1.97(\mathrm{~m}$, 1H), 1.81-1.74 (m, 12H), 1.63-1.58 (m, 4H), 1.32-1.27 (m, 6H), 1.13-1.10 (m, 3H), $0.96(\mathrm{~s}$, $3 \mathrm{H}), 0.86(\mathrm{~s}, 3 \mathrm{H}) ;{ }^{13} \mathrm{C} \mathrm{NMR}\left(100 \mathrm{MHz}, \mathrm{CDCl}_{3}\right) \delta 57.6,55.5,50.0,49.7,45.3,44.3,40.3,33.6$, 33.4, 32.4, 27.3, 26.6, 25.3, 21.1, 20.1; HRMS (TOF MS ES+) $m / z$ calcd for $\mathrm{C}_{22} \mathrm{H}_{40} \mathrm{NO}_{2} \mathrm{~S}_{2}(\mathrm{M}+$ $\mathrm{H})^{+} 414.2495$, found 414.2491; $[\alpha]_{\mathrm{D}}^{23}+27\left(c 0.51, \mathrm{CHCl}_{3}\right)$. 


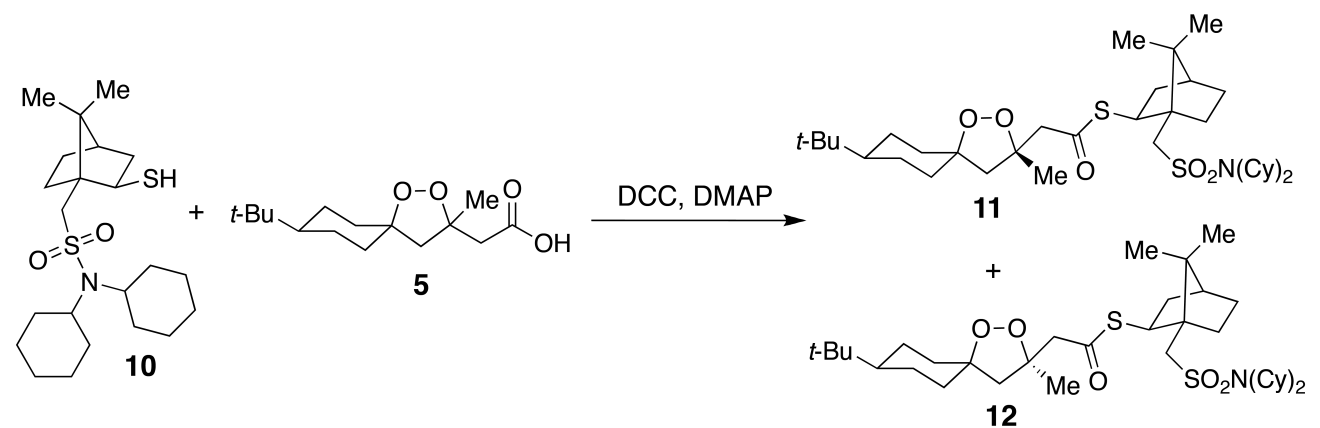

1,2-Dioxolanes 11 and 12. To a solution of 1,2-dioxolane $5(0.047 \mathrm{~g}, 0.172 \mathrm{mmol})$ and $\mathrm{CH}_{2} \mathrm{Cl}_{2}$ $(866 \mu \mathrm{L}, 0.2 \mathrm{M})$ were added 4-(dimethylamino)pyridine (DMAP, $0.005 \mathrm{~g}, 0.043 \mathrm{mmol})$ and $N, N^{\prime}$-dicyclohexylcarbodiimide (DCC, $\left.0.043 \mathrm{~g}, 0.021 \mathrm{mmol}\right)$. After $5 \mathrm{~min}$, thiol 10 (0.108 g, $0.260 \mathrm{mmol}$ ) was added to the solution. After $90 \mathrm{~min}$, the reaction mixture was diluted with $\mathrm{CH}_{2} \mathrm{Cl}_{2}(10 \mathrm{~mL})$, filtered through celite, and concentrated under reduced pressure. Purification by flash column chromatography (7\% EtOAc in hexanes) afforded a mixture of 1,2-dioxolanes 11 and 12 as an oil $(0.093$ g, 80\%). Further purification by flash column chromatography (15\% $\mathrm{Et}_{2} \mathrm{O}$ in hexanes) afforded 1,2-dioxolane $11(0.026 \mathrm{~g})$ as the first diastereomer to elute: ${ }^{1} \mathrm{H}$ NMR $\left(600 \mathrm{MHz}, \mathrm{CDCl}_{3}\right) \delta 4.05-4.03(\mathrm{dd}, J=9.3,5.2 \mathrm{~Hz}, 1 \mathrm{H}), 3.27-3.22(\mathrm{~m}, 2 \mathrm{H}), 3.21-3.19(\mathrm{~d}, J=$ 13.7 Hz, 1H), 3.00-2.98 (d, $J=14.8 \mathrm{~Hz}, 1 \mathrm{H}), 2.90-2.88(\mathrm{~d}, J=14.8 \mathrm{~Hz}, 1 \mathrm{H}), 2.73-2.71(\mathrm{~d}, J=$ $13.7 \mathrm{~Hz}, 1 \mathrm{H}), 2.57-2.55(\mathrm{~d}, J=12.6 \mathrm{~Hz}, 1 \mathrm{H}), 2.18-2.09(\mathrm{~m}, 4 \mathrm{H}), 1.94-1.91(\mathrm{~m}, 1 \mathrm{H}), 1.84-1.75$ (m, 17H), 1.64-1.57 (m, 4H), 1.54-1.49 (m, 1H), $1.43(\mathrm{~s}, 1 \mathrm{H}), 1.40(\mathrm{~s}, 2 \mathrm{H}), 1.34-1.20(\mathrm{~m}, 7 \mathrm{H})$ 1.14-1.07 (m, 2H), 0.97- $0.93(\mathrm{~m}, 1 \mathrm{H}), 0.89(\mathrm{~s}, 3 \mathrm{H}), 0.88(\mathrm{~s}, 3 \mathrm{H}), 0.83(\mathrm{~s}, 9 \mathrm{H}) ;{ }^{13} \mathrm{C}$ NMR $(150$ $\mathrm{MHz}, \mathrm{CDCl}_{3}$, the multiplicity of resolvable carbon peaks was determined using HSQC) $\delta 194.2$ (C), $85.0(\mathrm{C}), 83.6(\mathrm{C}), 57.4(\mathrm{CH}), 56.7,55.6\left(\mathrm{CH}_{2}\right), 52.9\left(\mathrm{CH}_{2}\right), 50.6(\mathrm{C}), 49.6(\mathrm{C}), 48.0(\mathrm{CH})$, 47.0, 45.5, 41.0, 36.0. 35.9, 33.8, 32.43, 32.37, 30.3, $27.5\left(\mathrm{CH}_{3}\right), 27.3,26.6,25.3,23.9,23.7$, 23.6, $20.6\left(\mathrm{CH}_{3}\right), 20.2\left(\mathrm{CH}_{3}\right)$; IR (ATR) 2939, 2859, 1684, 1323, $1143 \mathrm{~cm}^{-1}$; HRMS (TOF MS 
$\mathrm{ES}+) m / z$ calcd for $\mathrm{C}_{37} \mathrm{H}_{64} \mathrm{NO}_{5} \mathrm{~S}_{2}(\mathrm{M}+\mathrm{H})^{+} 666.4220$, found $666.4226 ;[\alpha]_{\mathrm{D}}{ }^{23}+42(c 0.86$, $\left.\mathrm{CHCl}_{3}\right)$.

1,2-Dioxolane 12 (0.0276 g) was the second product to elute: ${ }^{1} \mathrm{H}$ NMR (600 MHz, $\left.\mathrm{CDCl}_{3}\right) \delta 4.04-4.01(\mathrm{dd}, J=9.2,5.2 \mathrm{~Hz}, 1 \mathrm{H}), 3.27-3.24(\mathrm{~m}, 2 \mathrm{H}), 3.18-3.15(\mathrm{~d}, J=13.7 \mathrm{~Hz}$ $1 \mathrm{H}), 3.00-2.98(\mathrm{~d}, J=14.5 \mathrm{~Hz}, 1 \mathrm{H}), 2.86-2.84(\mathrm{~d}, J=14.5 \mathrm{~Hz}, 1 \mathrm{H}), 2.72-2.69(\mathrm{~d}, J=13.7 \mathrm{~Hz}$, $1 \mathrm{H}), 2.48-2.46(\mathrm{~d}, J=12.5 \mathrm{~Hz}, 1 \mathrm{H}), 2.19-2.07(\mathrm{~m}, 4 \mathrm{H}), 1.95-1.93(\mathrm{~m}, 1 \mathrm{H}), 1.83-1.74(\mathrm{~m}, 17 \mathrm{H})$, 1.63-1.58 (m, 4H), 1.55-1.49 (m, 1H), $1.46(\mathrm{~s}, 2 \mathrm{H}) 1.43(\mathrm{~s}, 1 \mathrm{H}), 1.33-1.21(\mathrm{~m}, 7 \mathrm{H}), 1.13-1.06$ $(\mathrm{m}, 2 \mathrm{H}), 0.98-0.93(\mathrm{~m}, 1 \mathrm{H}), 0.90(\mathrm{~s}, 3 \mathrm{H}), 0.89(\mathrm{~s}, 3 \mathrm{H}), 0.83(\mathrm{~s}, 9 \mathrm{H}) ;{ }^{13} \mathrm{C}$ NMR $(150 \mathrm{MHz}$, $\mathrm{CDCl}_{3}$, the multiplicity of resolvable carbon peaks was determined using HSQC) $\delta 194.3$ (C), $84.9(\mathrm{C}), 83.8(\mathrm{C}), 57.3(\mathrm{CH}), 56.2,55.6\left(\mathrm{CH}_{2}\right), 52.9\left(\mathrm{CH}_{2}\right), 50.4(\mathrm{C}), 49.6(\mathrm{C}), 48.1(\mathrm{CH}), 47.0$, 45.5, 41.1, 36.0, 35.8, 33.9, 33.3, 32.4, 32.3, 30.3, $27.5\left(\mathrm{CH}_{3}\right), 27.4,26.5,26.5,25.2,24.2,23.9$, 23.6, $20.6\left(\mathrm{CH}_{3}\right), 20.2\left(\mathrm{CH}_{3}\right)$; IR (ATR) 2938, 2856, 1688, 1322, $1142 \mathrm{~cm}^{-1}$; HRMS (TOF MS $\mathrm{ES}+) m / z$ calcd for $\mathrm{C}_{37} \mathrm{H}_{64} \mathrm{NO}_{5} \mathrm{~S}_{2}(\mathrm{M}+\mathrm{H})^{+} 666.4220$, found 666.4222; $[\alpha]_{\mathrm{D}}{ }^{23}+15\left(c 1.2, \mathrm{CHCl}_{3}\right)$. Both 11 and 12 were oils when concentrated under reduced pressure; however, slow evaporation at $0{ }^{\circ} \mathrm{C}$ of a solution of $\mathbf{1 1}$ in hexanes provided crystalline material of sufficient quality for X-ray crystallography (see below).

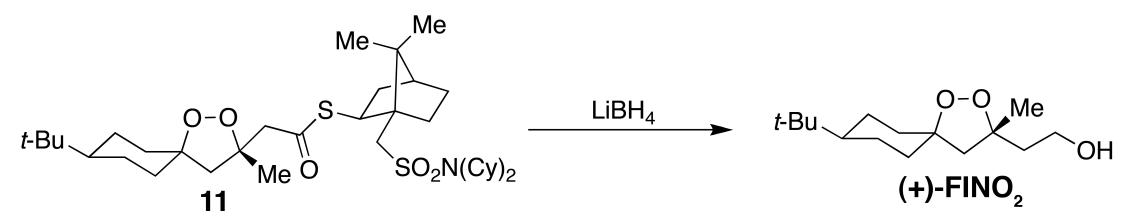

$(+)-\mathrm{FINO}_{2}$. Conditions to reduce an ethyl ester in the presence of a 1,2-dioxane ${ }^{22}$ were slightly modified to provide $(+)$-FINO 2 . To a cooled $\left(0^{\circ} \mathrm{C}\right)$ solution of 1,2-dioxolane $11(0.090 \mathrm{~g}, 0.135$ $\mathrm{mmol})$ in $\mathrm{Et}_{2} \mathrm{O}(2.7 \mathrm{~mL}, 0.05 \mathrm{M})$ was added lithium borohydride $\left(\mathrm{LiBH}_{4}, 0.009 \mathrm{~g}, 0.406 \mathrm{mmol}\right)$. After 20 minutes at $0{ }^{\circ} \mathrm{C}$, the reaction mixture was allowed to warm to room temperature. After 
$24 \mathrm{~h}$, the excess $\mathrm{LiBH}_{4}$ was quenched at $0{ }^{\circ} \mathrm{C}$ with saturated aqueous ammonium chloride $(1$ $\mathrm{mL})$. The reaction mixture was partitioned between water $(15 \mathrm{~mL})$ and EtOAc $(15 \mathrm{~mL})$. The organic layer was washed with brine $(20 \mathrm{~mL})$. The aqueous layers were combined and extracted with $\mathrm{Et}_{2} \mathrm{O}(3 \times 40 \mathrm{~mL})$. The organic extracts were combined, dried over $\mathrm{MgSO}_{4}$, filtered, and concentrated under reduced pressure. Purification by flash column chromatography (12-20\% EtOAc in hexanes) afforded (+)-FINO 2 as a white solid $(0.022 \mathrm{~g}, 62 \%)$ whose spectroscopic data matched those reported: $[\alpha]_{\mathrm{D}}^{23}+32\left(c 0.60, \mathrm{CHCl}_{3}\right)$.

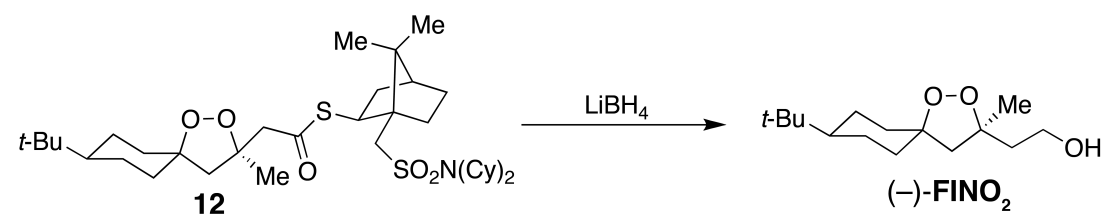

$(-)-F_{N N O}$. Conditions to reduce an ethyl ester in the presence of a 1,2-dioxane ${ }^{22}$ were slightly modified to provide (-)-FINO 2 . To a cooled $\left(0^{\circ} \mathrm{C}\right)$ solution of 1,2-dioxolane $12(0.090 \mathrm{~g}, 0.135$ $\mathrm{mmol})$ in $\mathrm{Et}_{2} \mathrm{O}(2.7 \mathrm{~mL}, 0.05 \mathrm{M})$ was added lithium borohydride $\left(\mathrm{LiBH}_{4}, 0.009 \mathrm{~g}, 0.406 \mathrm{mmol}\right)$. After 15 minutes at $0{ }^{\circ} \mathrm{C}$, the reaction mixture was allowed to warm to room temperature. After $24 \mathrm{~h}$, the excess $\mathrm{LiBH}_{4}$ was quenched at $0{ }^{\circ} \mathrm{C}$ with saturated aqueous ammonium chloride $(1$ $\mathrm{mL})$. The reaction mixture was partitioned between water $(15 \mathrm{~mL})$ and EtOAc $(15 \mathrm{~mL})$. The organic layer was washed with brine $(20 \mathrm{~mL})$. The aqueous layers were combined and extracted with $\mathrm{Et}_{2} \mathrm{O}(3 \times 40 \mathrm{~mL})$. The organic extracts were combined, dried over $\mathrm{MgSO}_{4}$, filtered, and concentrated under reduced pressure. Purification by flash column chromatography (12-30\% EtOAc in hexanes) afforded (-)-FINO ${ }_{2}$ as a white solid $(0.018 \mathrm{~g}, 51 \%)$ whose spectroscopic data matched those reported: with the following optical rotation $[\alpha]_{\mathrm{D}}^{23}-38\left(c 0.62, \mathrm{CHCl}_{3}\right)$. 


\section{X-ray Crystallographic Data}

X-ray Data Collection, Structure Solution and Refinement for 1,2-Dioxolane 11.

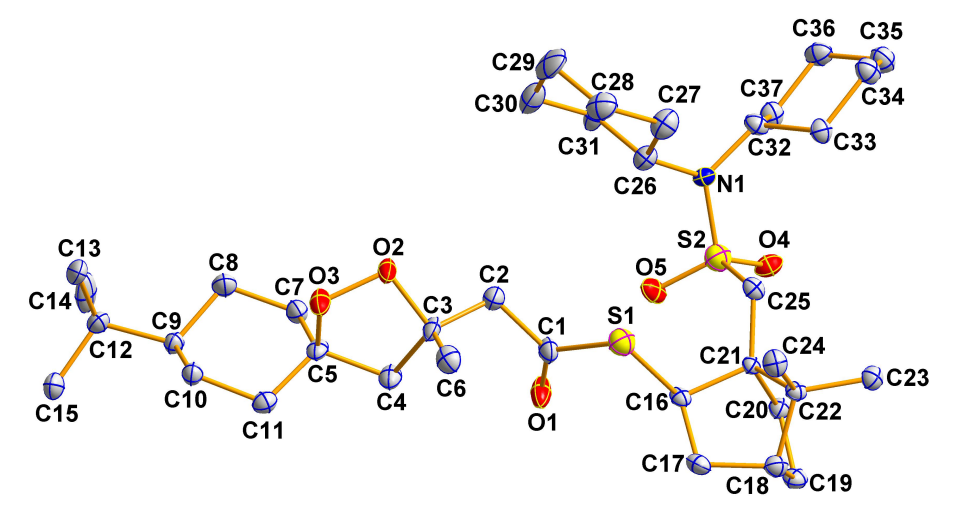

The molecular structure of dioxolane 11. The $\mathrm{H}$ atoms are omitted for clarity.

A colorless needle-like crystal with the size of $0.02 \cdot 0.04 \cdot 0.54 \mathrm{~mm}^{3}$ was selected for geometry and intensity data collection with a Bruker SMART APEXII CCD area detector on a D8 goniometer at $100 \mathrm{~K}$. The temperature during the data collection was controlled with an Oxford Cryosystems Series $700+$ instrument. Preliminary lattice parameters and orientation matrices were obtained from three sets of frames. Data were collected using graphite-monochromated and $0.5 \mathrm{~mm}-$ MonoCap-collimated Mo-K $\alpha$ radiation $(\lambda=0.71073 \AA)$ with the $\omega$ scan method ${ }^{[1]}$. Data were processed with the INTEGRATE program of the APEX2 software ${ }^{[1]}$ for reduction and cell refinement. Multi-scan absorption corrections were applied by using the SCALE program for the area detector. The structure was solved by the direct method and refined on $\mathrm{F}^{2}$ (SHELXTL) ${ }^{[2]}$. Non-hydrogen atoms were refined with anisotropic displacement parameters, and hydrogen atoms on carbons were placed in idealized positions $(\mathrm{C}-\mathrm{H}=0.98-1.00 \AA)$ and included as riding with $U_{\text {iso }}(\mathrm{H})=1.2$ or $1.5 U_{\text {eq }}($ non-H). 
References.

[1] APEX2 (version 2012.10). Program for Bruker CCD X-ray Diffractometer Control, Bruker

AXS Inc., Madison, WI, 2012.

[2] G. M. Sheldrick, SHELXTL, version 6.14. Program for solution and refinement of crystal

structures, Universität Göttingen, Germany, 2009.

\section{Sample and Crystal Data}

Chemical formula: $\mathrm{C}_{37} \mathrm{H}_{63} \mathrm{NO}_{5} \mathrm{~S}_{2}$

Formula weight: 666.03

Temperature: $100(2) \mathrm{K}$

Wavelength: $0.71073 \AA$

Crystal size: $0.020 \times 0.040 \times 0.540 \mathrm{~mm}$

Crystal habit: colorless needle

Crystal system: orthorhombic

Space group: P 212121

Unit cell dimensions:

$\mathrm{a}=6.5242(7) \AA ; \alpha=90^{\circ}$

$\mathrm{b}=18.975(2) \AA ; \beta=90^{\circ}$

$\mathrm{c}=29.829(3) \AA ; \gamma=90^{\circ}$

Volume: $3692.7(7) \AA^{3}$

Z: 4

Density (calculated): $1.198 \mathrm{~g} / \mathrm{cm}^{3}$

Absorption coefficient: $0.185 \mathrm{~mm}^{-1}$

$\mathrm{F}(000): 1456$

\section{Data Collection and Structure Refinement}

Diffractometer: Bruker APEX-II CCD

Radiation source: sealed tube, MoK $\alpha$

Theta range for data collection: 1.27 to $26.37^{\circ}$

Index ranges: $-7<=\mathrm{h}<=8,-23<=\mathrm{k}<=23,-36<=1<=37$

Reflections collected: 30801

Independent reflections: 7524 [R(int $)=0.0877]$

Absorption correction: multi-scan

Max. and min. transmission: 0.9963 and 0.9065

Structure solution technique: direct methods

Structure solution program: SHELXS-97 (Sheldrick, 2008)

Refinement method: Full-matrix least-squares on $\mathrm{F}^{2}$

Refinement program: SHELXL-97 (Sheldrick, 2008)

Function minimized: $\Sigma \mathrm{w}\left(\mathrm{F}_{\mathrm{o}}{ }^{2}-\mathrm{F}_{\mathrm{c}}{ }^{2}\right)^{2}$ 
Data / restraints / parameters: 7524 / 0 / 413

Goodness-of-fit on F2: 1.036

$\Delta / \sigma \max : 0.001$

Final R indices: 5683 data; $\mathrm{I}>2 \sigma(\mathrm{I}) ; \mathrm{R} 1=0.0503$, wR2 $=0.1008$

all data: $\mathrm{R} 1=0.0792, \mathrm{wR} 2=0.1117$

Weighting scheme: $\mathrm{w}=1 /\left[\sigma^{2}\left(\mathrm{~F}_{\mathrm{o}}{ }^{2}\right)+(0.0489 \mathrm{P})^{2}+0.0000 \mathrm{P}\right]$

where $\mathrm{P}=\left(\mathrm{F}_{\mathrm{o}}{ }^{2}+2 \mathrm{~F}_{\mathrm{c}}{ }^{2}\right) / 3$

Absolute structure parameter: 0.0(1)

Largest diff. peak and hole: 0.226 and $-0.371 \mathrm{e}^{-3}$

R.M.S. deviation from mean: $0.056 \mathrm{e}^{-3 \mathrm{a}}$

Atomic coordinates and equivalent isotropic atomic displacement parameters $\left(\AA^{2}\right)$ :

$\mathrm{U}(\mathrm{eq})$ is defined as one third of the trace of the orthogonalized Uij tensor.

\begin{tabular}{lllll} 
& \multicolumn{1}{c}{$\mathrm{x} / \mathrm{a}$} & $\mathrm{y} / \mathrm{b}$ & \multicolumn{1}{c}{$\mathrm{z} / \mathrm{c}$} & $\mathrm{U}(\mathrm{eq})$ \\
$\mathrm{S} 1$ & $0.31155(12)$ & $0.60129(4)$ & $0.47390(3)$ & $0.02229(19)$ \\
$\mathrm{S} 2$ & $0.40087(12)$ & $0.53423(4)$ & $0.35323(3)$ & $0.01863(17)$ \\
$\mathrm{O} 1$ & $0.7114(3)$ & $0.58204(13)$ & $0.48444(8)$ & $0.0345(6)$ \\
$\mathrm{O} 2$ & $0.5158(3)$ & $0.42777(12)$ & $0.58384(7)$ & $0.0290(6)$ \\
$\mathrm{O} 3$ & $0.6349(3)$ & $0.42529(11)$ & $0.62540(7)$ & $0.0283(5)$ \\
$\mathrm{O} 4$ & $0.4609(3)$ & $0.55196(11)$ & $0.30823(7)$ & $0.0249(5)$ \\
$\mathrm{O} 5$ & $0.5565(3)$ & $0.53002(11)$ & $0.38713(7)$ & $0.0268(5)$ \\
$\mathrm{N} 1$ & $0.2795(4)$ & $0.45925(12)$ & $0.35180(8)$ & $0.0183(5)$ \\
$\mathrm{C} 1$ & $0.5418(5)$ & $0.55989(17)$ & $0.49172(10)$ & $0.0231(7)$ \\
$\mathrm{C} 2$ & $0.5042(5)$ & $0.49223(16)$ & $0.51776(10)$ & $0.0241(7)$ \\
$\mathrm{C} 3$ & $0.5558(5)$ & $0.49850(16)$ & $0.56717(10)$ & $0.0212(7)$ \\
$\mathrm{C} 4$ & $0.7843(5)$ & $0.50910(17)$ & $0.57750(11)$ & $0.0247(8)$ \\
$\mathrm{C} 5$ & $0.8364(4)$ & $0.45085(15)$ & $0.61134(10)$ & $0.0206(7)$ \\
$\mathrm{C} 6$ & $0.4190(5)$ & $0.55116(17)$ & $0.59070(10)$ & $0.0272(8)$ \\
$\mathrm{C} 7$ & $0.9580(5)$ & $0.39065(17)$ & $0.59032(10)$ & $0.0238(7)$ \\
$\mathrm{C} 8$ & $0.0158(5)$ & $0.33314(16)$ & $0.62365(10)$ & $0.0256(8)$ \\
$\mathrm{C} 9$ & $0.1332(5)$ & $0.36390(15)$ & $0.66372(9)$ & $0.0183(7)$ \\
$\mathrm{C} 10$ & $0.9933(5)$ & $0.41801(15)$ & $0.68674(9)$ & $0.0201(7)$ \\
$\mathrm{C} 11$ & $0.9380(5)$ & $0.47723(16)$ & $0.65420(10)$ & $0.0221(7)$ \\
$\mathrm{C} 12$ & $0.2227(5)$ & $0.30788(15)$ & $0.69618(10)$ & $0.0230(7)$ \\
$\mathrm{C} 13$ & $0.0560(6)$ & $0.26720(18)$ & $0.72064(11)$ & $0.0339(9)$ \\
$\mathrm{C} 14$ & $0.3594(7)$ & $0.25702(19)$ & $0.66968(12)$ & $0.0424(11)$ \\
C15 & $0.3588(5)$ & $0.34437(17)$ & $0.73091(11)$ & $0.0267(8)$ \\
C16 & $0.4138(5)$ & $0.66600(15)$ & $0.43471(9)$ & $0.0166(6)$ \\
C17 & $0.3983(5)$ & $0.74374(16)$ & $0.45087(10)$ & $0.0222(7)$ \\
C18 & $0.3054(5)$ & $0.78138(16)$ & $0.41031(10)$ & $0.0213(7)$ \\
C19 & $0.4670(5)$ & $0.78186(16)$ & $0.37291(10)$ & $0.0216(7)$ \\
C20 & $0.4670(4)$ & $0.70359(15)$ & $0.35675(10)$ & $0.0182(7)$ \\
C21 & $0.3067(4)$ & $0.66801(14)$ & $0.38786(9)$ & $0.0141(6)$
\end{tabular}




$\begin{array}{lllll}\text { C22 } & 0.1450(4) & 0.72793(15) & 0.39327(9) & 0.0164(6) \\ \text { C23 } & 0.0418(5) & 0.75050(16) & 0.34924(10) & 0.0206(7) \\ \text { C24 } & 0.9751(5) & 0.71122(17) & 0.42706(10) & 0.0229(7) \\ \text { C25 } & 0.2174(4) & 0.59891(15) & 0.37085(10) & 0.0174(6) \\ \text { C26 } & 0.2351(5) & 0.42539(16) & 0.39574(10) & 0.0228(7) \\ \text { C27 } & 0.0075(5) & 0.42234(18) & 0.40725(11) & 0.0292(8) \\ \text { C28 } & 0.9723(6) & 0.38755(18) & 0.45286(11) & 0.0330(9) \\ \text { C29 } & 0.0748(7) & 0.31544(19) & 0.45584(12) & 0.0424(10) \\ \text { C30 } & 0.3004(6) & 0.31891(19) & 0.44398(11) & 0.0379(9) \\ \text { C31 } & 0.3366(6) & 0.35353(16) & 0.39867(10) & 0.0272(8) \\ \text { C32 } & 0.1660(5) & 0.43423(16) & 0.31161(10) & 0.0211(7) \\ \text { C33 } & 0.9914(5) & 0.48193(16) & 0.29678(10) & 0.0213(7) \\ \text { C34 } & 0.8706(5) & 0.44820(17) & 0.25901(10) & 0.0267(8) \\ \text { C35 } & 0.0042(5) & 0.42609(18) & 0.22041(11) & 0.0285(8) \\ \text { C36 } & 0.1800(5) & 0.37962(16) & 0.23494(10) & 0.0255(7) \\ \text { C37 } & 0.3042(5) & 0.41394(17) & 0.27299(10) & 0.0247(7)\end{array}$

Bond lengths ( $\AA$ ):

$\begin{array}{llll}\text { S1-C1 } & 1.776(3) & \text { S1-C16 } & 1.822(3) \\ \text { S2-O5 } & 1.435(2) & \text { S2-O4 } & 1.438(2) \\ \text { S2-N1 } & 1.629(2) & \text { S2-C25 } & 1.793(3) \\ \text { O1-C1 } & 1.204(4) & \text { O2-C3 } & 1.455(4) \\ \text { O2-O3 } & 1.464(3) & \text { O3-C5 } & 1.462(3) \\ \text { N1-C32 } & 1.487(4) & \text { N1-C26 } & 1.488(4) \\ \text { C1-C2 } & 1.521(4) & \text { C2-C3 } & 1.516(4) \\ \text { C2-H2A } & 0.99 & \text { C2-H2B } & 0.99 \\ \text { C3-C6 } & 1.512(4) & \text { C3-C4 } & 1.535(4) \\ \text { C4-C5 } & 1.535(4) & \text { C4-H4A } & 0.99 \\ \text { C4-H4B } & 0.99 & \text { C5-C11 } & 1.525(4) \\ \text { C5-C7 } & 1.526(4) & \text { C6-H6A } & 0.98 \\ \text { C6-H6B } & 0.98 & \text { C6-H6C } & 0.98 \\ \text { C7-C8 } & 1.523(4) & \text { C7-H7A } & 0.99 \\ \text { C7-H7B } & 0.99 & \text { C8-C9 } & 1.535(4) \\ \text { C8-H8A } & 0.99 & \text { C8-H8B } & 0.99 \\ \text { C9-C10 } & 1.536(4) & \text { C9-C12 } & 1.552(4) \\ \text { C9-H9 } & 1 & \text { C10-C11 } & 1.528(4) \\ \text { C10-H10A } & 0.99 & \text { C10-H10B } & 0.99 \\ \text { C11-H11A } & 0.99 & \text { C11-H11B } & 0.99 \\ \text { C12-C13 } & 1.520(5) & \text { C12-C15 } & 1.530(4) \\ \text { C12-C14 } & 1.533(5) & \text { C13-H13A } & 0.98 \\ \text { C13-H13B } & 0.98 & \text { C13-H13C } & 0.98 \\ \text { C14-H14A } & 0.98 & \text { C14-H14B } & 0.98 \\ \text { C14-H14C } & 0.98 & \text { C15-H15A } & 0.98 \\ \text { C15-H15B } & 0.98 & \text { C15-H15C } & 0.98 \\ \text { C16-C17 } & 1.555(4) & \text { C16-C21 } & 1.563(4) \\ \end{array}$




\begin{tabular}{|c|c|c|c|}
\hline C16-H16 & 1 & C17-C18 & $1.530(4)$ \\
\hline C17-H17A & 0.99 & C17-H17B & 0.99 \\
\hline C18-C19 & $1.535(4)$ & $\mathrm{C} 18-\mathrm{C} 22$ & $1.543(4)$ \\
\hline C18-H18 & 1 & C19-C20 & $1.562(4)$ \\
\hline C19-H19A & 0.99 & C19-H19B & 0.99 \\
\hline C20-C21 & $1.553(4)$ & C20-H20A & 0.99 \\
\hline C20-H20B & 0.99 & C21-C25 & $1.522(4)$ \\
\hline C21-C22 & $1.560(4)$ & C22-C24 & $1.531(4)$ \\
\hline C22-C23 & $1.537(4)$ & $\mathrm{C} 23-\mathrm{H} 23 \mathrm{~A}$ & 0.98 \\
\hline C23-H23B & 0.98 & $\mathrm{C} 23-\mathrm{H} 23 \mathrm{C}$ & 0.98 \\
\hline $\mathrm{C} 24-\mathrm{H} 24 \mathrm{~A}$ & 0.98 & C24-H24B & 0.98 \\
\hline $\mathrm{C} 24-\mathrm{H} 24 \mathrm{C}$ & 0.98 & $\mathrm{C} 25-\mathrm{H} 25 \mathrm{~A}$ & 0.99 \\
\hline $\mathrm{C} 25-\mathrm{H} 25 \mathrm{~B}$ & 0.99 & C26-C31 & $1.518(4)$ \\
\hline C26-C27 & $1.525(4)$ & C26-H26 & 1 \\
\hline C27-C28 & $1.530(4)$ & $\mathrm{C} 27-\mathrm{H} 27 \mathrm{~A}$ & 0.99 \\
\hline C27-H27B & 0.99 & C28-C29 & $1.526(5)$ \\
\hline C28-H28A & 0.99 & C28-H28B & 0.99 \\
\hline C29-C30 & $1.515(6)$ & C29-H29A & 0.99 \\
\hline C29-H29B & 0.99 & C30-C31 & $1.521(4)$ \\
\hline C30-H30A & 0.99 & C30-H30B & 0.99 \\
\hline C31-H31A & 0.99 & C31-H31B & 0.99 \\
\hline C32-C37 & $1.512(4)$ & C32-C33 & $1.521(4)$ \\
\hline C32-H32 & 1 & C33-C34 & $1.516(4)$ \\
\hline C33-H33A & 0.99 & C33-H33B & 0.99 \\
\hline C34-C35 & $1.504(4)$ & C34-H34A & 0.99 \\
\hline C34-H34B & 0.99 & C35-C36 & $1.510(4)$ \\
\hline C35-H35A & 0.99 & C35-H35B & 0.99 \\
\hline C36-C37 & $1.539(4)$ & C36-H36A & 0.99 \\
\hline C36-H36B & 0.99 & C37-H37A & 0.99 \\
\hline C37-H37B & 0.99 & & \\
\hline
\end{tabular}

\section{Bond angles $\left({ }^{\circ}\right)$ :}

$\begin{array}{llll}\text { C1-S1-C16 } & 100.39(15) & & \\ \text { O5-S2-O4 } & 118.56(13) & & \\ \text { O5-S2-N1 } & 108.28(13) & \text { O4-S2-N1 } & 108.19(13) \\ \text { O5-S2-C25 } & 107.69(13) & \text { O4-S2-C25 } & 107.17(13) \\ \text { N1-S2-C25 } & 106.33(14) & \text { C3-O2-O3 } & 102.9(2) \\ \text { C5-O3-O2 } & 102.92(18) & \text { C32-N1-C26 } & 118.4(2) \\ \text { C32-N1-S2 } & 122.83(19) & \text { C26-N1-S2 } & 116.7(2) \\ \text { O1-C1-C2 } & 122.4(3) & \text { O1-C1-S1 } & 124.7(2) \\ \text { C2-C1-S1 } & 113.0(2) & \text { C3-C2-C1 } & 113.2(3) \\ \text { C3-C2-H2A } & 108.9 & \text { C1-C2-H2A } & 108.9 \\ \text { C3-C2-H2B } & 108.9 & \text { C1-C2-H2B } & 108.9 \\ \text { H2A-C2-H2B } & 107.7 & \text { O2-C3-C6 } & 110.2(2) \\ \text { O2-C3-C2 } & 102.7(2) & \text { C6-C3-C2 } & 111.8(3)\end{array}$




\begin{tabular}{|c|c|c|c|}
\hline $\mathrm{O} 2-\mathrm{C} 3-\mathrm{C} 4$ & $103.1(2)$ & C6-C3-C4 & $113.1(3)$ \\
\hline $\mathrm{C} 2-\mathrm{C} 3-\mathrm{C} 4$ & $114.9(3)$ & $\mathrm{C} 5-\mathrm{C} 4-\mathrm{C} 3$ & $104.6(2)$ \\
\hline C5-C4-H4A & 110.8 & C3-C4-H4A & 110.8 \\
\hline C5-C4-H4B & 110.8 & C3-C4-H4B & 110.8 \\
\hline $\mathrm{H} 4 \mathrm{~A}-\mathrm{C} 4-\mathrm{H} 4 \mathrm{~B}$ & 108.9 & O3-C5-C11 & $105.0(2)$ \\
\hline $\mathrm{O} 3-\mathrm{C} 5-\mathrm{C} 7$ & $109.7(2)$ & C11-C5-C7 & $111.3(2)$ \\
\hline $\mathrm{O} 3-\mathrm{C} 5-\mathrm{C} 4$ & $103.2(2)$ & C11-C5-C4 & $114.3(3)$ \\
\hline C7-C5-C4 & $112.6(2)$ & C3-C6-H6A & 109.5 \\
\hline C3-C6-H6B & 109.5 & H6A-C6-H6B & 109.5 \\
\hline C3-C6-H6C & 109.5 & H6A-C6-H6C & 109.5 \\
\hline H6B-C6-H6C & 109.5 & $\mathrm{C} 8-\mathrm{C} 7-\mathrm{C} 5$ & $113.4(2)$ \\
\hline C8-C7-H7A & 108.9 & C5-C7-H7A & 108.9 \\
\hline C8-C7-H7B & 108.9 & C5-C7-H7B & 108.9 \\
\hline H7A-C7-H7B & 107.7 & C7-C8-C9 & $111.0(2)$ \\
\hline C7-C8-H8A & 109.4 & C9-C8-H8A & 109.4 \\
\hline C7-C8-H8B & 109.4 & C9-C8-H8B & 109.4 \\
\hline H8A-C8-H8B & 108 & C8-C9-C10 & $107.8(2)$ \\
\hline C8-C9-C12 & $114.4(2)$ & C10-C9-C12 & $113.7(2)$ \\
\hline C8-C9-H9 & 106.8 & C10-C9-H9 & 106.8 \\
\hline C12-C9-H9 & 106.8 & C11-C10-C9 & $110.3(2)$ \\
\hline C11-C10-H10A & 109.6 & C9-C10-H10A & 109.6 \\
\hline C11-C10-H10B & 109.6 & C9-C10-H10B & 109.6 \\
\hline H10A-C10-H10B & 108.1 & C5-C11-C10 & $113.2(2)$ \\
\hline C5-C11-H11A & 108.9 & C10-C11-H11A & 108.9 \\
\hline C5-C11-H11B & 108.9 & C10-C11-H11B & 108.9 \\
\hline H11A-C11-H11B & 107.8 & C13-C12-C15 & $108.7(3)$ \\
\hline C13-C12-C14 & $110.1(3)$ & $\mathrm{C} 15-\mathrm{C} 12-\mathrm{C} 14$ & $107.3(3)$ \\
\hline C13-C12-C9 & $112.2(3)$ & C15-C12-C9 & $109.3(2)$ \\
\hline C14-C12-C9 & $109.2(2)$ & C12-C13-H13A & 109.5 \\
\hline C12-C13-H13B & 109.5 & H13A-C13-H13B & 109.5 \\
\hline C12-C13-H13C & 109.5 & H13A-C13-H13C & 109.5 \\
\hline H13B-C13-H13C & 109.5 & C12-C14-H14A & 109.5 \\
\hline C12-C14-H14B & 109.5 & H14A-C14-H14B & 109.5 \\
\hline C12-C14-H14C & 109.5 & H14A-C14-H14C & 109.5 \\
\hline H14B-C14-H14C & 109.5 & C12-C15-H15A & 109.5 \\
\hline C12-C15-H15B & 109.5 & H15A-C15-H15B & 109.5 \\
\hline C12-C15-H15C & 109.5 & H15A-C15-H15C & 109.5 \\
\hline H15B-C15-H15C & 109.5 & C17-C16-C21 & $103.0(2)$ \\
\hline C17-C16-S1 & $114.6(2)$ & C21-C16-S1 & $115.2(2)$ \\
\hline C17-C16-H16 & 107.9 & C21-C16-H16 & 107.9 \\
\hline S1-C16-H16 & 107.9 & C18-C17-C16 & $102.9(2)$ \\
\hline C18-C17-H17A & 111.2 & C16-C17-H17A & 111.2 \\
\hline C18-C17-H17B & 111.2 & C16-C17-H17B & 111.2 \\
\hline H17A-C17-H17B & 109.1 & C17-C18-C19 & $107.8(3)$ \\
\hline C17-C18-C22 & $102.8(2)$ & C19-C18-C22 & $103.3(2)$ \\
\hline C17-C18-H18 & 113.9 & C19-C18-H18 & 113.9 \\
\hline
\end{tabular}




\begin{tabular}{|c|c|c|c|}
\hline C22-C18-H18 & 113.9 & C18-C19-C20 & $102.6(2)$ \\
\hline C18-C19-H19A & 111.2 & C20-C19-H19A & 111.2 \\
\hline C18-C19-H19B & 111.2 & C20-C19-H19B & 111.2 \\
\hline H19A-C19-H19B & 109.2 & C21-C20-C19 & $103.2(2)$ \\
\hline C21-C20-H20A & 111.1 & C19-C20-H20A & 111.1 \\
\hline C21-C20-H20B & 111.1 & C19-C20-H20B & 111.1 \\
\hline H20A-C20-H20B & 109.1 & C25-C21-C20 & $115.7(2)$ \\
\hline $\mathrm{C} 25-\mathrm{C} 21-\mathrm{C} 22$ & $113.8(2)$ & $\mathrm{C} 20-\mathrm{C} 21-\mathrm{C} 22$ & $101.6(2)$ \\
\hline C25-C21-C16 & $116.6(2)$ & $\mathrm{C} 20-\mathrm{C} 21-\mathrm{C} 16$ & $104.1(2)$ \\
\hline C22-C21-C16 & $103.2(2)$ & $\mathrm{C} 24-\mathrm{C} 22-\mathrm{C} 23$ & $107.6(2)$ \\
\hline C24-C22-C18 & $114.2(2)$ & $\mathrm{C} 23-\mathrm{C} 22-\mathrm{C} 18$ & $113.3(2)$ \\
\hline C24-C22-C21 & $114.0(2)$ & C23-C22-C21 & $114.3(2)$ \\
\hline C18-C22-C21 & $93.1(2)$ & C22-C23-H23A & 109.5 \\
\hline C22-C23-H23B & 109.5 & $\mathrm{H} 23 \mathrm{~A}-\mathrm{C} 23-\mathrm{H} 23 \mathrm{~B}$ & 109.5 \\
\hline C22-C23-H23C & 109.5 & $\mathrm{H} 23 \mathrm{~A}-\mathrm{C} 23-\mathrm{H} 23 \mathrm{C}$ & 109.5 \\
\hline $\mathrm{H} 23 \mathrm{~B}-\mathrm{C} 23-\mathrm{H} 23 \mathrm{C}$ & 109.5 & C22-C24-H24A & 109.5 \\
\hline C22-C24-H24B & 109.5 & $\mathrm{H} 24 \mathrm{~A}-\mathrm{C} 24-\mathrm{H} 24 \mathrm{~B}$ & 109.5 \\
\hline C22-C24-H24C & 109.5 & $\mathrm{H} 24 \mathrm{~A}-\mathrm{C} 24-\mathrm{H} 24 \mathrm{C}$ & 109.5 \\
\hline H24B-C24-H24C & 109.5 & $\mathrm{C} 21-\mathrm{C} 25-\mathrm{S} 2$ & $115.6(2)$ \\
\hline C21-C25-H25A & 108.4 & $\mathrm{~S} 2-\mathrm{C} 25-\mathrm{H} 25 \mathrm{~A}$ & 108.4 \\
\hline C21-C25-H25B & 108.4 & $\mathrm{~S} 2-\mathrm{C} 25-\mathrm{H} 25 \mathrm{~B}$ & 108.4 \\
\hline $\mathrm{H} 25 \mathrm{~A}-\mathrm{C} 25-\mathrm{H} 25 \mathrm{~B}$ & 107.4 & N1-C26-C31 & $110.7(3)$ \\
\hline N1-C26-C27 & $113.8(3)$ & C31-C26-C27 & $112.2(3)$ \\
\hline N1-C26-H26 & 106.5 & C31-C26-H26 & 106.5 \\
\hline C27-C26-H26 & 106.5 & C26-C27-C28 & $111.3(3)$ \\
\hline C26-C27-H27A & 109.4 & C28-C27-H27A & 109.4 \\
\hline C26-C27-H27B & 109.4 & C28-C27-H27B & 109.4 \\
\hline H27A-C27-H27B & 108 & C29-C28-C27 & $111.9(3)$ \\
\hline C29-C28-H28A & 109.2 & C27-C28-H28A & 109.2 \\
\hline C29-C28-H28B & 109.2 & C27-C28-H28B & 109.2 \\
\hline H28A-C28-H28B & 107.9 & C30-C29-C28 & $111.9(3)$ \\
\hline C30-C29-H29A & 109.2 & C28-C29-H29A & 109.2 \\
\hline С30-C29-H29B & 109.2 & С28-C29-H29B & 109.2 \\
\hline H29A-C29-H29B & 107.9 & C29-C30-C31 & $112.2(3)$ \\
\hline C29-C30-H30A & 109.2 & C31-C30-H30A & 109.2 \\
\hline C29-C30-H30B & 109.2 & C31-C30-H30B & 109.2 \\
\hline H30A-C30-H30B & 107.9 & C26-C31-C30 & $111.8(3)$ \\
\hline C26-C31-H31A & 109.3 & C30-C31-H31A & 109.3 \\
\hline C26-C31-H31B & 109.3 & C30-C31-H31B & 109.3 \\
\hline H31A-C31-H31B & 107.9 & N1-C32-C37 & $113.5(2)$ \\
\hline N1-C32-C33 & $114.7(2)$ & C37-C32-C33 & $112.1(2)$ \\
\hline N1-C32-H32 & 105.1 & C37-C32-H32 & 105.1 \\
\hline C33-C32-H32 & 105.1 & C34-C33-C32 & $110.7(2)$ \\
\hline C34-C33-H33A & 109.5 & C32-C33-H33A & 109.5 \\
\hline C34-C33-H33B & 109.5 & С32-C33-H33B & 109.5 \\
\hline H33A-C33-H33В & 108.1 & C35-C34-C33 & $112.7(3)$ \\
\hline
\end{tabular}




$\begin{array}{llll}\text { C35-C34-H34A } & 109.1 & \text { C33-C34-H34A } & 109.1 \\ \text { C35-C34-H34B } & 109.1 & \text { C33-C34-H34B } & 109.1 \\ \text { H34A-C34-H34B } & 107.8 & \text { C34-C35-C36 } & 112.5(3) \\ \text { C34-C35-H35A } & 109.1 & \text { C36-C35-H35A } & 109.1 \\ \text { C34-C35-H35B } & 109.1 & \text { C36-C35-H35B } & 109.1 \\ \text { H35A-C35-H35B } & 107.8 & \text { C35-C36-C37 } & 111.4(3) \\ \text { C35-C36-H36A } & 109.4 & \text { C37-C36-H36A } & 109.4 \\ \text { C35-C36-H36B } & 109.4 & \text { C37-C36-H36B } & 109.4 \\ \text { H36A-C36-H36B } & 108 & \text { C32-C37-C36 } & 110.8(3) \\ \text { C32-C37-H37A } & 109.5 & \text { C36-C37-H37A } & 109.5 \\ \text { C32-C37-H37B } & 109.5 & \text { C36-C37-H37B } & 109.5 \\ \text { H37A-C37-H37B } & 108.1 & & \end{array}$

\section{Anisotropic atomic displacement parameters $\left(\AA^{2}\right)$ :}

The anisotropic atomic displacement factor exponent takes the form: $-2 \pi 2[\mathrm{~h} 2 \mathrm{a} * 2 \mathrm{U} 11+\ldots+2 \mathrm{~h}$ $\mathrm{k} \mathrm{a}{ }^{*} \mathrm{~b} * \mathrm{U} 12$ ]

\begin{tabular}{lllllll} 
& \multicolumn{1}{c}{$\mathrm{U} 11$} & $\mathrm{U} 22$ & $\mathrm{U} 33$ & $\mathrm{U} 23$ & $\mathrm{U} 13$ & $\mathrm{U} 12$ \\
S1 & $0.0167(4)$ & $0.0293(4)$ & $0.0209(4)$ & $0.0076(3)$ & $0.0003(4)$ & $0.0012(4)$ \\
S2 & $0.0144(4)$ & $0.0173(4)$ & $0.0242(4)$ & $0.0005(3)$ & $0.0010(3)$ & $0.0005(3)$ \\
O1 & $0.0193(12)$ & $0.0461(16)$ & $0.0381(14)$ & $0.0239(12)$ & $-0.0070(11)$ & $-0.0075(11)$ \\
O2 & $0.0235(12)$ & $0.0317(13)$ & $0.0318(13)$ & $0.0184(10)$ & $-0.0114(11)$ & $-0.0106(11)$ \\
O3 & $0.0188(12)$ & $0.0360(13)$ & $0.0300(12)$ & $0.0170(10)$ & $-0.0048(10)$ & $-0.0086(10)$ \\
O4 & $0.0245(12)$ & $0.0208(12)$ & $0.0295(12)$ & $0.0011(10)$ & $0.0076(10)$ & $-0.0023(10)$ \\
O5 & $0.0172(12)$ & $0.0267(12)$ & $0.0364(13)$ & $-0.0061(10)$ & $-0.0079(10)$ & $0.0059(10)$ \\
N1 & $0.0204(13)$ & $0.0141(13)$ & $0.0204(13)$ & $-0.0004(11)$ & $0.0011(11)$ & $-0.0024(11)$ \\
C1 & $0.0230(17)$ & $0.0287(18)$ & $0.0175(15)$ & $0.0066(14)$ & $-0.0031(14)$ & $-0.0018(15)$ \\
C2 & $0.0254(18)$ & $0.0214(17)$ & $0.0255(17)$ & $0.0051(14)$ & $-0.0044(15)$ & $-0.0011(14)$ \\
C3 & $0.0178(17)$ & $0.0214(17)$ & $0.0245(17)$ & $0.0121(14)$ & $-0.0009(14)$ & $-0.0009(13)$ \\
C4 & $0.0180(17)$ & $0.0280(18)$ & $0.0282(18)$ & $0.0094(14)$ & $-0.0014(14)$ & $-0.0047(14)$ \\
C5 & $0.0153(15)$ & $0.0213(17)$ & $0.0251(17)$ & $0.0081(13)$ & $-0.0003(13)$ & $-0.0050(13)$ \\
C6 & $0.0243(18)$ & $0.035(2)$ & $0.0219(17)$ & $0.0021(14)$ & $0.0028(15)$ & $-0.0022(16)$ \\
C7 & $0.0257(18)$ & $0.0257(18)$ & $0.0200(16)$ & $0.0016(14)$ & $-0.0042(14)$ & $-0.0034(15)$ \\
C8 & $0.0318(19)$ & $0.0199(17)$ & $0.0251(17)$ & $-0.0024(14)$ & $-0.0042(15)$ & $0.0015(15)$ \\
C9 & $0.0199(17)$ & $0.0167(16)$ & $0.0184(15)$ & $0.0011(12)$ & $-0.0011(13)$ & $0.0025(13)$ \\
C10 & $0.0220(16)$ & $0.0196(17)$ & $0.0188(15)$ & $0.0011(13)$ & $-0.0016(14)$ & $0.0020(14)$ \\
C11 & $0.0211(17)$ & $0.0205(17)$ & $0.0245(17)$ & $0.0003(13)$ & $0.0020(14)$ & $-0.0008(14)$ \\
C12 & $0.0290(18)$ & $0.0162(16)$ & $0.0239(16)$ & $0.0009(13)$ & $-0.0035(15)$ & $0.0016(14)$ \\
C13 & $0.047(2)$ & $0.0247(19)$ & $0.0304(18)$ & $0.0115(15)$ & $-0.0151(18)$ & $-0.0085(17)$ \\
C14 & $0.058(3)$ & $0.037(2)$ & $0.0322(19)$ & $-0.0019(16)$ & $-0.0109(19)$ & $0.032(2)$ \\
C15 & $0.027(2)$ & $0.0243(17)$ & $0.0285(18)$ & $0.0036(14)$ & $-0.0067(15)$ & $0.0042(15)$ \\
C16 & $0.0126(15)$ & $0.0217(16)$ & $0.0157(15)$ & $0.0010(12)$ & $0.0004(13)$ & $-0.0042(14)$ \\
C17 & $0.0207(16)$ & $0.0250(17)$ & $0.0209(15)$ & $-0.0041(13)$ & $-0.0021(15)$ & $-0.0062(15)$ \\
C18 & $0.0195(16)$ & $0.0187(16)$ & $0.0257(17)$ & $-0.0017(13)$ & $-0.0011(15)$ & $0.0001(15)$
\end{tabular}




$\begin{array}{lllcccc}\text { C19 } & 0.0173(16) & 0.0212(17) & 0.0264(17) & 0.0007(14) & -0.0007(14) & -0.0039(14) \\ \text { C20 } & 0.0149(15) & 0.0197(16) & 0.0200(15) & 0.0025(13) & -0.0005(13) & -0.0006(13) \\ \text { C21 } & 0.0112(14) & 0.0152(15) & 0.0159(14) & 0.0013(12) & -0.0011(13) & -0.0007(13) \\ \text { C22 } & 0.0128(16) & 0.0165(15) & 0.0197(15) & -0.0005(12) & 0.0000(12) & -0.0006(12) \\ \text { C23 } & 0.0176(16) & 0.0216(17) & 0.0227(16) & 0.0013(14) & 0.0006(14) & 0.0017(13) \\ \text { C24 } & 0.0195(17) & 0.0276(18) & 0.0217(16) & -0.0007(14) & 0.0027(14) & 0.0038(15) \\ \text { C25 } & 0.0123(15) & 0.0216(16) & 0.0183(15) & -0.0019(13) & 0.0010(12) & 0.0013(13) \\ \text { C26 } & 0.0249(18) & 0.0203(17) & 0.0233(16) & 0.0029(14) & 0.0014(14) & 0.0004(14) \\ \text { C27 } & 0.0289(19) & 0.030(2) & 0.0292(18) & 0.0035(15) & 0.0084(16) & 0.0036(16) \\ \text { C28 } & 0.038(2) & 0.033(2) & 0.0282(18) & 0.0012(16) & 0.0084(17) & -0.0060(17) \\ \text { C29 } & 0.066(3) & 0.031(2) & 0.0301(19) & 0.0140(16) & 0.010(2) & -0.009(2) \\ \text { C30 } & 0.058(3) & 0.0245(19) & 0.032(2) & 0.0066(15) & 0.003(2) & 0.008(2) \\ \text { C31 } & 0.037(2) & 0.0206(17) & 0.0245(17) & 0.0031(13) & 0.0037(16) & 0.0098(16) \\ \text { C32 } & 0.0160(16) & 0.0234(17) & 0.0238(16) & -0.0033(13) & -0.0016(14) & -0.0003(14) \\ \text { C33 } & 0.0174(16) & 0.0240(17) & 0.0225(16) & 0.0003(14) & -0.0006(14) & 0.0021(14) \\ \text { C34 } & 0.0231(17) & 0.0281(19) & 0.0289(18) & -0.0035(14) & -0.0032(15) & 0.0034(15) \\ \text { C35 } & 0.0300(19) & 0.0290(19) & 0.0266(17) & -0.0044(15) & -0.0043(16) & 0.0022(16) \\ \text { C36 } & 0.0310(19) & 0.0227(17) & 0.0228(16) & -0.0044(14) & 0.0039(16) & -0.0012(16) \\ \text { C37 } & 0.0235(17) & 0.0249(18) & 0.0256(17) & -0.0019(14) & 0.0003(15) & 0.0068(15)\end{array}$

Hydrogen atomic coordinates and isotropic atomic displacement parameters $\left(\AA^{2}\right)$ :

$\begin{array}{lllll} & \mathrm{x} / \mathrm{a} & \mathrm{y} / \mathrm{b} & \mathrm{z} / \mathrm{c} & \mathrm{U}(\mathrm{eq}) \\ \mathrm{H} 2 \mathrm{~A} & 0.3582 & 0.4788 & 0.5147 & 0.029 \\ \text { H2B } & 0.5878 & 0.454 & 0.5045 & 0.029 \\ \text { H4A } & 0.8678 & 0.5042 & 0.55 & 0.03 \\ \text { H4B } & 0.8089 & 0.5563 & 0.5906 & 0.03 \\ \text { H6A } & 0.4507 & 0.5988 & 0.58 & 0.041 \\ \text { H6B } & 0.4425 & 0.5486 & 0.6231 & 0.041 \\ \text { H6C } & 0.2753 & 0.5402 & 0.5842 & 0.041 \\ \text { H7A } & 0.8758 & 0.3695 & 0.5659 & 0.029 \\ \text { H7B } & 1.0848 & 0.41 & 0.5768 & 0.029 \\ \text { H8A } & 1.102 & 0.2974 & 0.6085 & 0.031 \\ \text { H8B } & 0.89 & 0.3095 & 0.6345 & 0.031 \\ \text { H9 } & 1.2521 & 0.3907 & 0.6512 & 0.022 \\ \text { H10A } & 0.8666 & 0.3945 & 0.6972 & 0.024 \\ \text { H10B } & 1.064 & 0.438 & 0.7132 & 0.024 \\ \text { H11A } & 0.8441 & 0.5105 & 0.6694 & 0.026 \\ \text { H11B } & 1.0642 & 0.5033 & 0.6462 & 0.026 \\ \text { H13A } & 0.9683 & 0.2432 & 0.6987 & 0.051 \\ \text { H13B } & 0.9731 & 0.2999 & 0.7385 & 0.051 \\ \text { H13C } & 1.1191 & 0.2322 & 0.7405 & 0.051 \\ \text { H14A } & 1.274 & 0.2278 & 0.6501 & 0.064 \\ \text { H14B } & 1.4349 & 0.2267 & 0.6906 & 0.064 \\ \text { H14C } & 1.4567 & 0.284 & 0.6515 & 0.064\end{array}$




$\begin{array}{lllll}\text { H15A } & 1.4645 & 0.372 & 0.7155 & 0.04 \\ \text { H15B } & 1.4241 & 0.3088 & 0.75 & 0.04 \\ \text { H15C } & 1.2748 & 0.3757 & 0.7495 & 0.04 \\ \text { H16 } & 0.562 & 0.655 & 0.4298 & 0.02 \\ \text { H17A } & 0.3082 & 0.7478 & 0.4774 & 0.027 \\ \text { H17B } & 0.5352 & 0.763 & 0.4583 & 0.027 \\ \text { H18 } & 0.2476 & 0.8289 & 0.4173 & 0.026 \\ \text { H19A } & 0.6032 & 0.7958 & 0.3846 & 0.026 \\ \text { H19B } & 0.4276 & 0.8143 & 0.3484 & 0.026 \\ \text { H20A } & 0.4256 & 0.7001 & 0.3249 & 0.022 \\ \text { H20B } & 0.604 & 0.6819 & 0.3605 & 0.022 \\ \text { H23A } & 0.1471 & 0.7614 & 0.3269 & 0.031 \\ \text { H23B } & -0.0425 & 0.7924 & 0.3546 & 0.031 \\ \text { H23C } & -0.0451 & 0.7121 & 0.3382 & 0.031 \\ \text { H24A } & -0.1051 & 0.7539 & 0.4329 & 0.034 \\ \text { H24B } & 0.0364 & 0.6945 & 0.4551 & 0.034 \\ \text { H24C } & -0.1147 & 0.6746 & 0.4148 & 0.034 \\ \text { H25A } & 0.1257 & 0.6094 & 0.3453 & 0.021 \\ \text { H25B } & 0.1323 & 0.5782 & 0.3949 & 0.021 \\ \text { H26 } & 0.3013 & 0.4555 & 0.4191 & 0.027 \\ \text { H27A } & -0.0659 & 0.3953 & 0.3838 & 0.035 \\ \text { H27B } & -0.0492 & 0.4707 & 0.4077 & 0.035 \\ \text { H28A } & 0.0275 & 0.4184 & 0.4767 & 0.04 \\ \text { H28B } & -0.1768 & 0.3822 & 0.458 & 0.04 \\ \text { H29A } & 0.0597 & 0.2969 & 0.4867 & 0.051 \\ \text { H29B } & 0.005 & 0.2824 & 0.4352 & 0.051 \\ \text { H30A } & 0.3575 & 0.2706 & 0.4435 & 0.046 \\ \text { H30B } & 0.374 & 0.3459 & 0.4674 & 0.046 \\ \text { H31A } & 0.4859 & 0.3588 & 0.3937 & 0.033 \\ \text { H31B } & 0.2816 & 0.3228 & 0.3747 & 0.033 \\ \text { H32 } & 0.0987 & 0.3893 & 0.3212 & 0.025 \\ \text { H33A } & -0.1008 & 0.4911 & 0.3225 & 0.026 \\ \text { H33B } & 0.0476 & 0.5277 & 0.2866 & 0.026 \\ \text { H34A } & -0.2026 & 0.4064 & 0.2707 & 0.032 \\ \text { H34B } & -0.2334 & 0.4821 & 0.2481 & 0.032 \\ \text { H35A } & 0.0596 & 0.4687 & 0.2055 & 0.034 \\ \text { H35B } & -0.0803 & 0.4004 & 0.1982 & 0.034 \\ \text { H36A } & 0.2712 & 0.3708 & 0.209 & 0.031 \\ \text { H36B } & 0.1257 & 0.3337 & 0.2453 & 0.031 \\ \text { H37A } & 0.41 & 0.3805 & 0.2837 & 0.03 \\ \text { H37B } & 0.3746 & 0.4565 & 0.2615 & 0.03\end{array}$




\section{Selected Spectra}

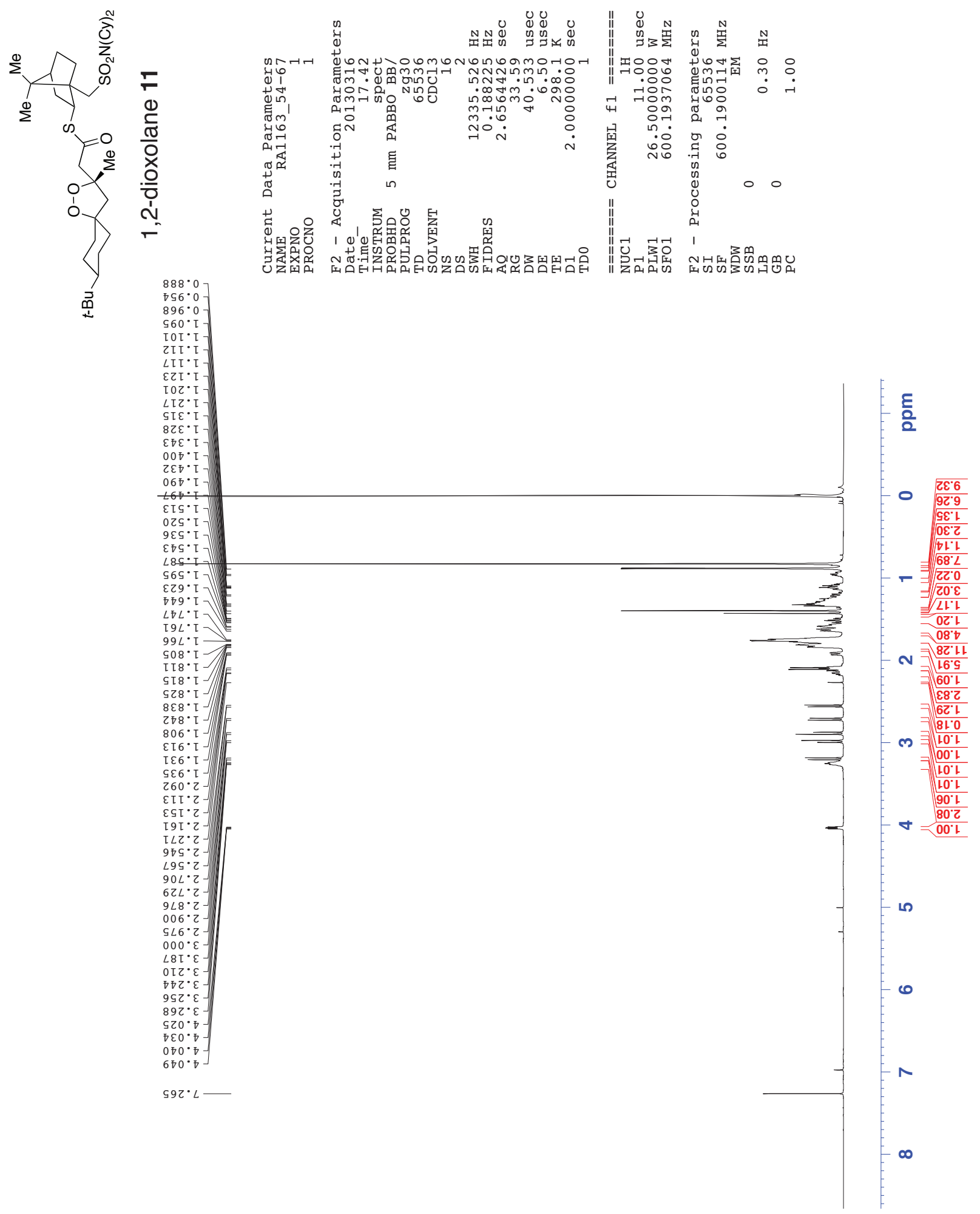




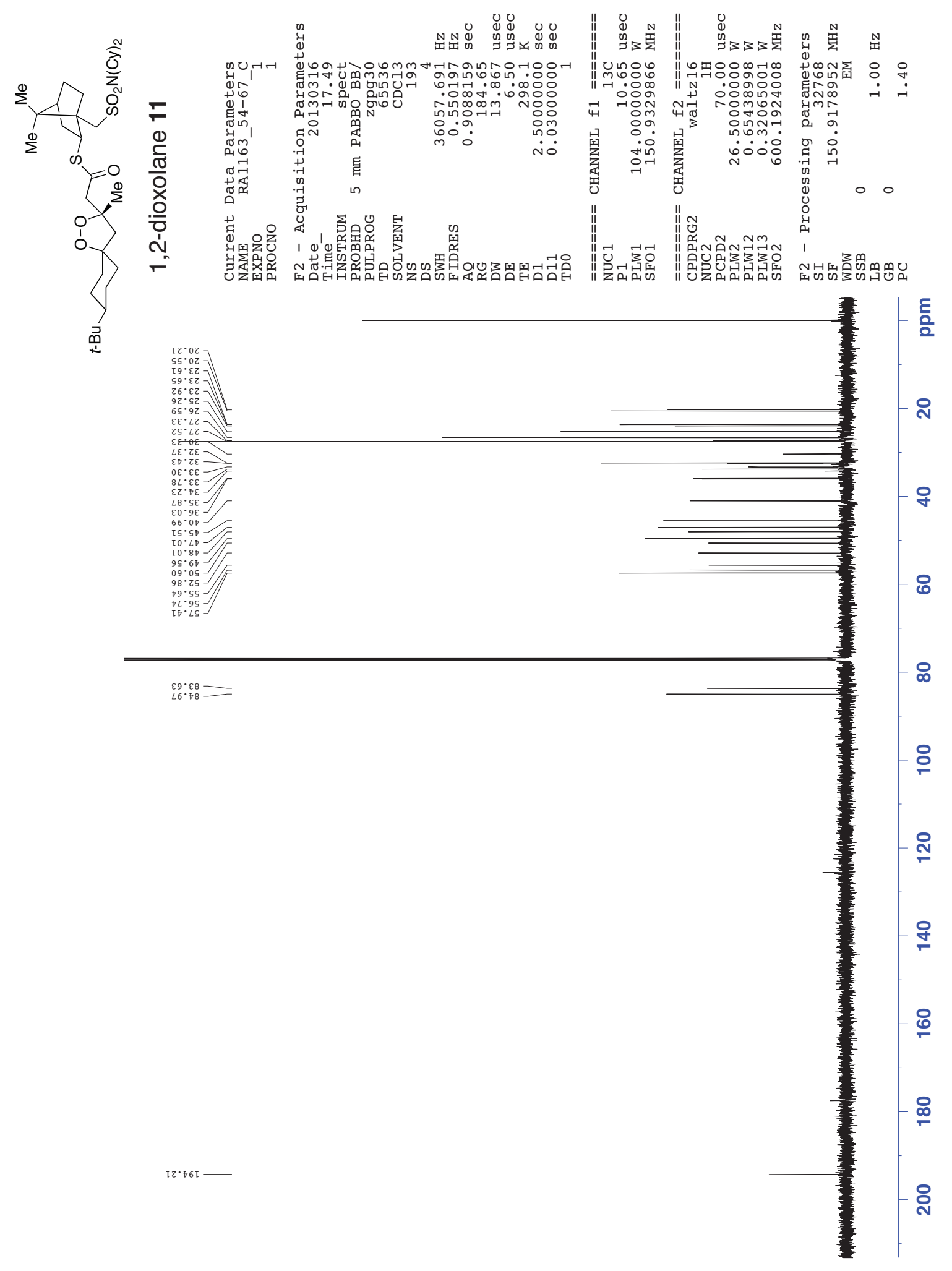




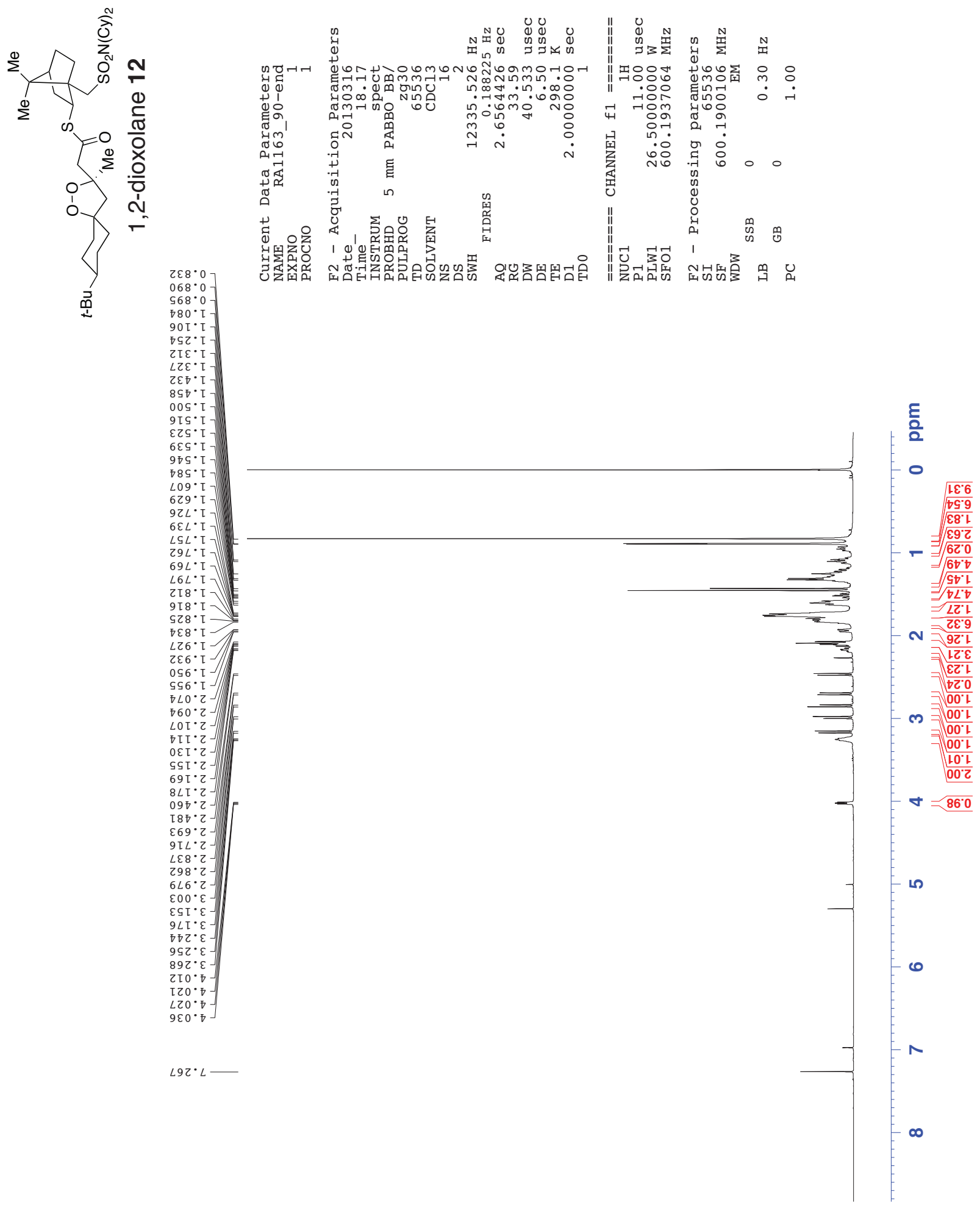



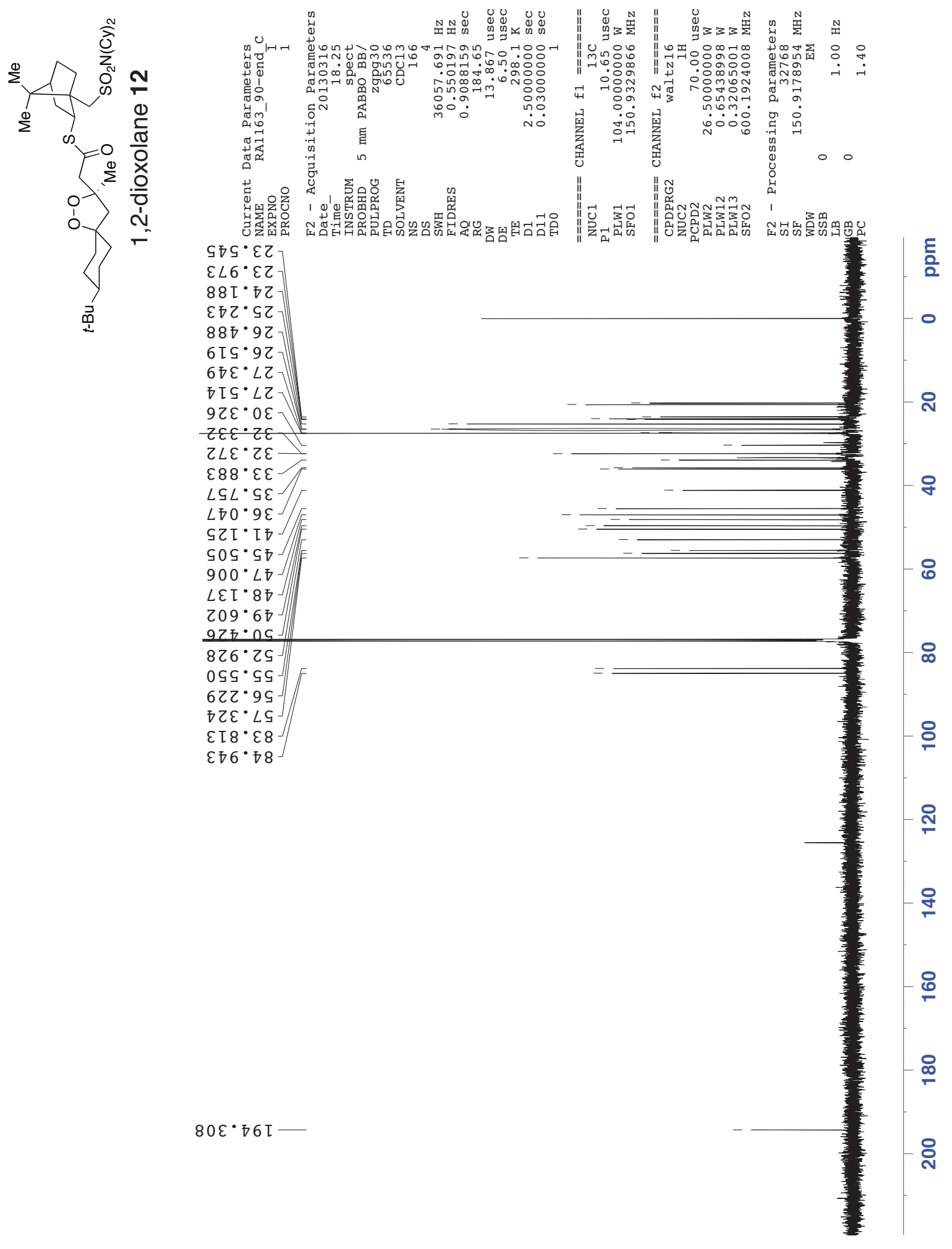

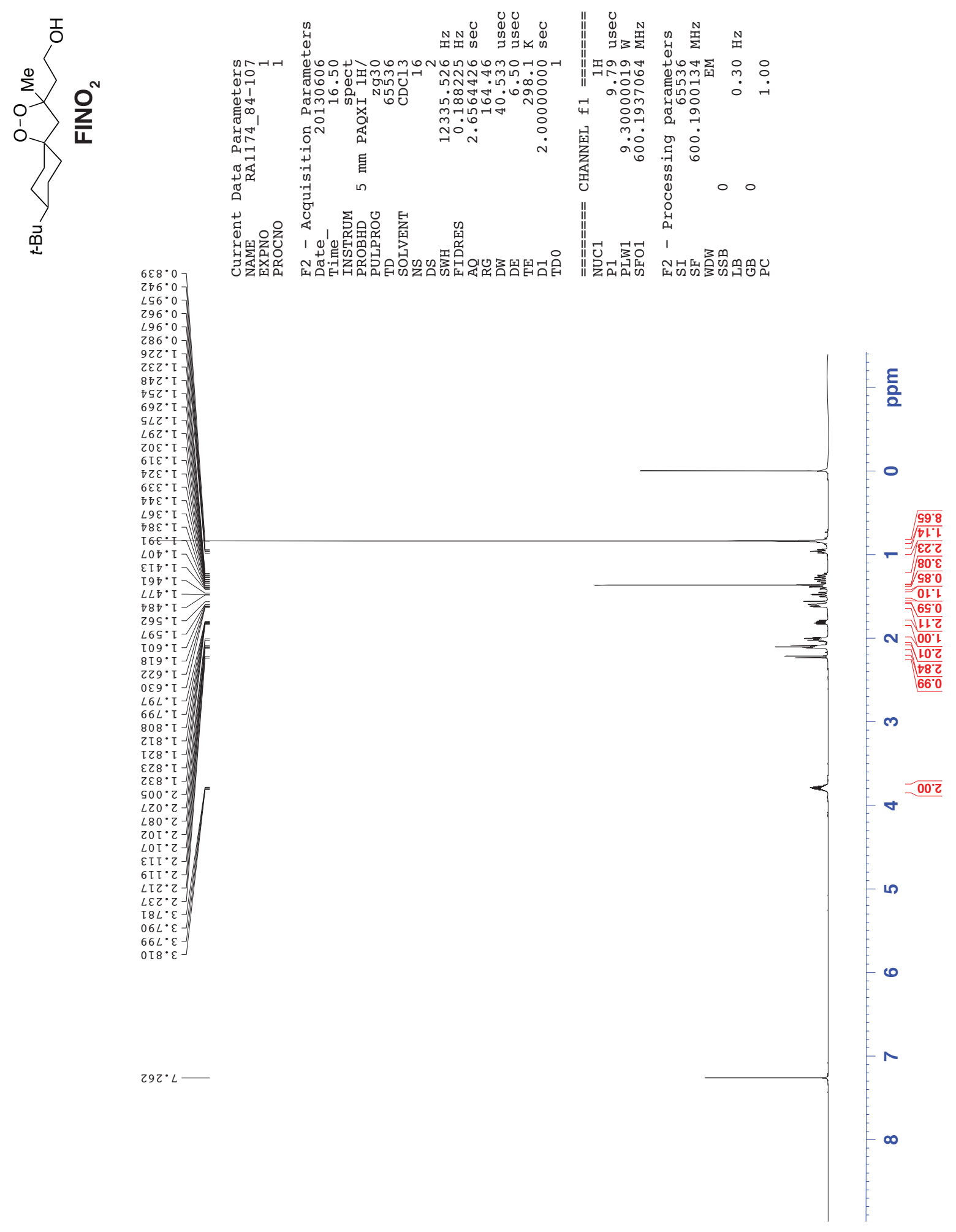

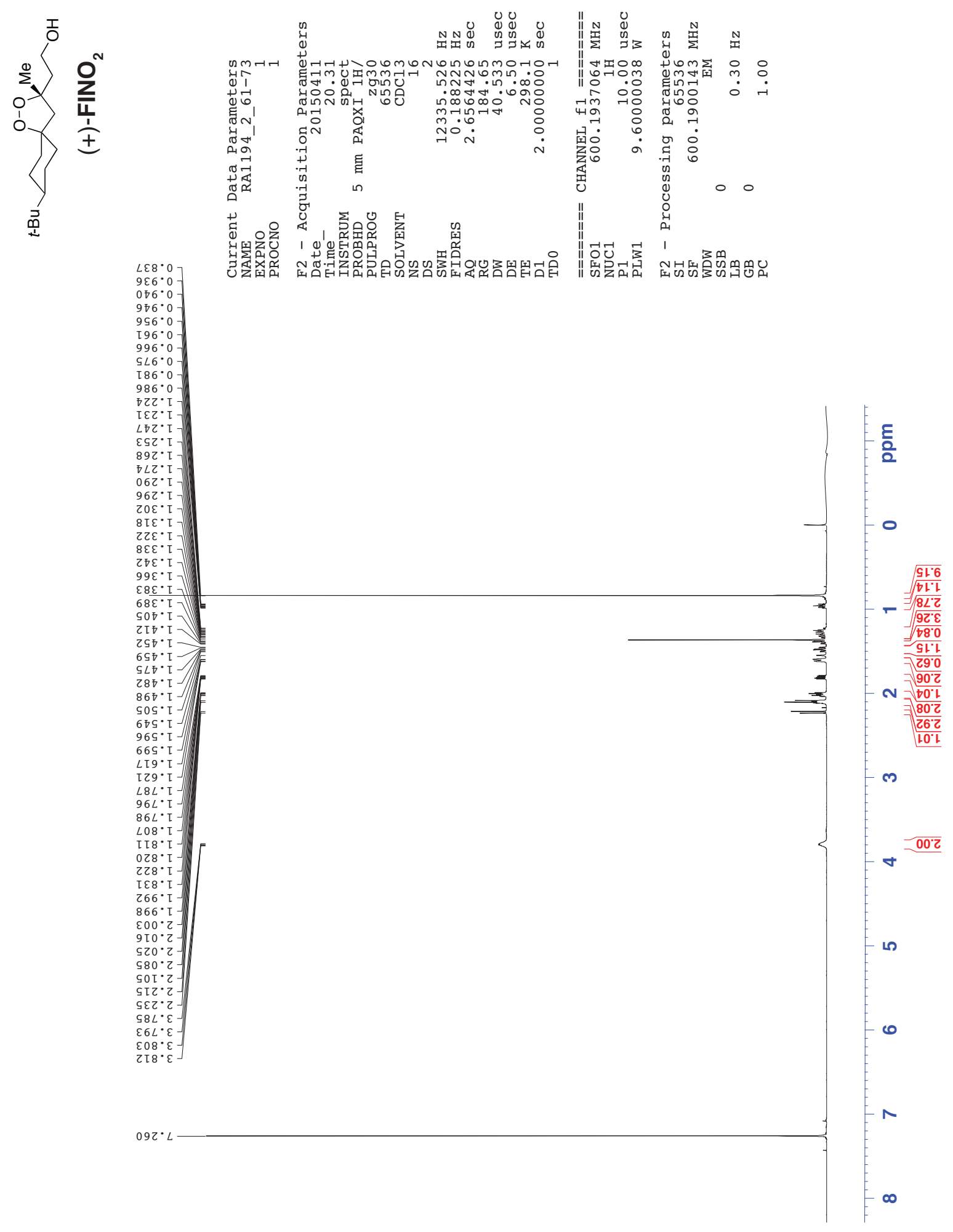

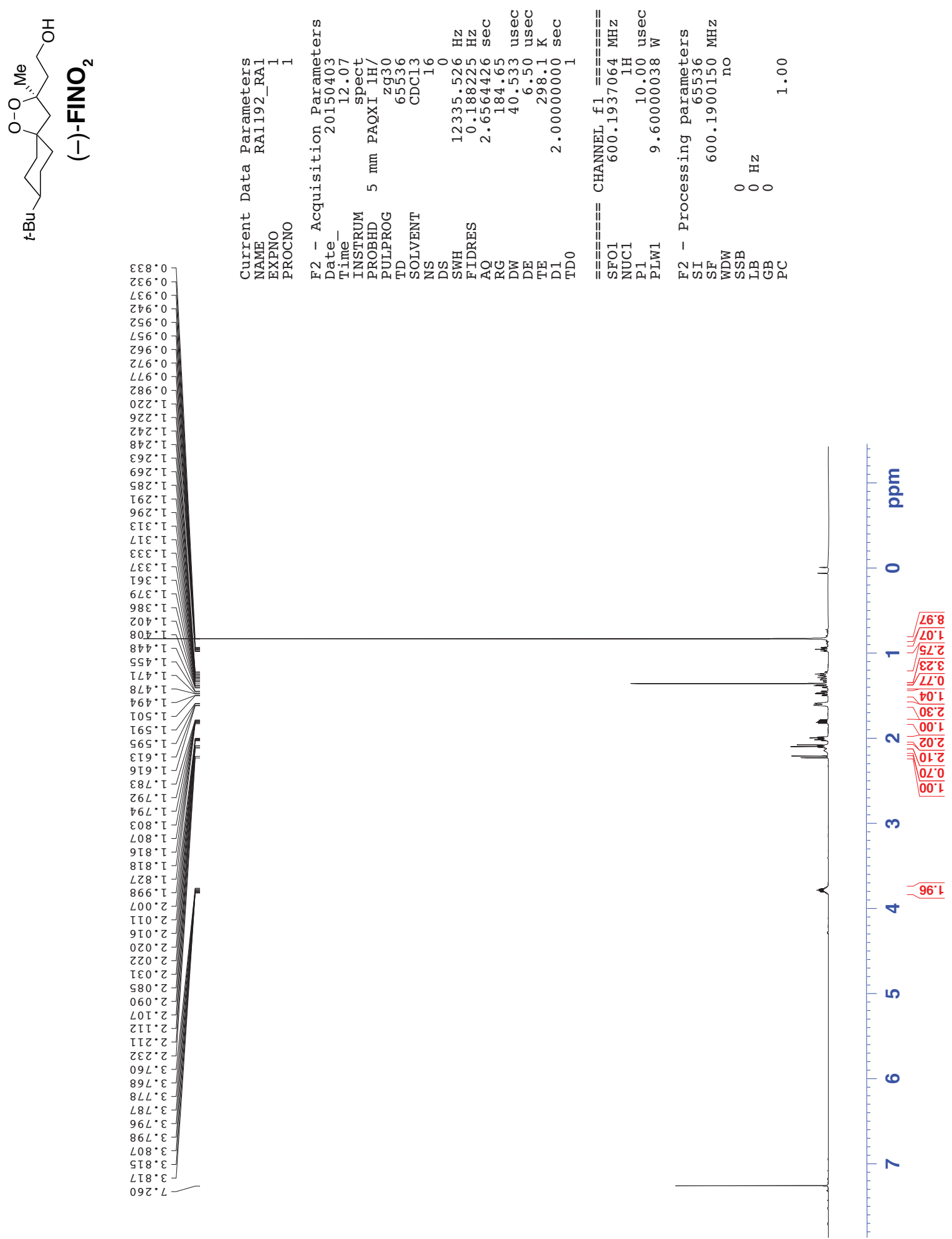


\section{References}

1. Gratzner, H. G. (1982) Monoclonal antibody to 5-bromo- and 5-iododeoxyuridine: A new reagent for detection of DNA replication, Science 218, 474-475.

2. Ramirez, A., and Woerpel, K. A. (2005) Synthesis of 1,2-Dioxolanes by Annulation Reactions of Peroxycarbenium Ions with Alkenes, Org. Lett. 7, 4617-4620.

3. Li, Y., Hao, H.-D., Zhang, Q., and Wu, Y. (2009) A Broadly Applicable Mild Method for the Synthesis of gem-Diperoxides from Corresponding Ketones or 1,3-Dioxolanes, Org. Lett. 11, $1615-1618$.

4. Giron, D. (2002) Applications of Thermal Analysis and Coupled Techniques in Pharmaceutical Industry, J. Therm. Anal. Calorim. 68, 335-357.

5. Stong, R. C., Korsmeyer, S. J., Parkin, J. L., Arthur, D. C., and Kersey, J. H. (1985) Human acute leukemia cell line with the $\mathrm{t}(4 ; 11)$ chromosomal rearrangement exhibits B lineage and monocytic characteristics, Blood 65, 21-31.

6. Bodnar, A. G., Ouellette, M., Frolkis, M., Holt, S. E., Chiu, C.-P., Morin, G. B., et al. (1998) Extension of Life-Span by Introduction of Telomerase into Normal Human Cells, Science 279, $349-352$.

7. Jiang, X.-R., Jimenez, G., Chang, E., Frolkis, M., Kusler, B., Sage, M., et al. (1999)

Telomerase expression in human somatic cells does not induce changes associated with a transformed phenotype, Nat. Genet. 21, 111-114.

8. Pear, W. S., Nolan, G. P., Scott, M. L., and Baltimore, D. (1993) Production of high-titer helper-free retroviruses by transient transfection, Proc. Natl. Acad. Sci. U. S. A. 90, 8392-8396.

9. Hahn, W. C., Counter, C. M., Lundberg, A. S., Beijersbergen, R. L., Brooks, M. W., and Weinberg, R. A. (1999) Creation of human tumour cells with defined genetic elements, Nature $400,464-468$. 
10. Cheng, Z., Gong, Y., Ma, Y., Lu, K., Lu, X., Pierce, L. A., et al. (2013) Inhibition of BET Bromodomain Targets Genetically Diverse Glioblastoma, Clin. Cancer Res. 19, 1748-1759.

11. Chen, C., and Okayama, H. (1987) High-efficiency transformation of mammalian cells by plasmid DNA, Mol. Cell. Biol. 7, 2745-2752.

12. Ishiura, M., Hirose, S., Uchida, T., Hamada, Y., Suzuki, Y., and Okada, Y. (1982) Phage Particle-Mediated Gene Transfer to Cultured Mammalian Cells, Mol. Cell. Biol. 2, 607-616. 13. Gottlieb, H. E., Kotlyar, V., and Nudelman, A. (1997) NMR chemical shifts of common laboratory solvents as trace impurities, J. Org. Chem. 62, 7512-7515.

14. Pangborn, A. B., Giardello, M. A., Grubbs, R. H., Rosen, R. K., and Timmers, F. J. (1996) Safe and Convenient Procedure for Solvent Purification, Organometallics 15, 1518-1520.

15. McCloskey, C. M. (1989) Safe handling of organic peroxides: An overview, Plant/Operations Progress 8, 185-188.

16. Gaunt, M. J., Hook, D. F., Tanner, H. R., and Ley, S. V. (2003) A Practical and Efficient Synthesis of the C-16-C-28 Spiroketal Fragment (CD) of the Spongistatins, Org. Lett. 5, 48154818.

17. Petronijevic, F. R., and Wipf, P. (2011) Total Synthesis of ( \pm )-Cycloclavine and ( \pm )-5-epiCycloclavine, J. Am. Chem. Soc. 133, 7704-7707.

18. Zhao, M., Li, J., Mano, E., Song, Z., Tschaen, D. M., Grabowski, E. J. J., et al. (1999) Oxidation of Primary Alcohols to Carboxylic Acids with Sodium Chlorite Catalyzed by TEMPO and Bleach, J. Org. Chem. 64, 2564-2566.

19. Knoppe, S., Kothalawala, N., Jupally, V. R., Dass, A., and Burgi, T. (2012) Ligand dependence of the synthetic approach and chiroptical properties of a magic cluster protected with a bicyclic chiral thiolate, Chem. Commun. 48, 4630-4632. 
20. Oppolzer, W., Chapuis, C., and Bernardinelli, G. (1984) Asymmetric diels-alder reactions : facile preparation and structure of sulfonamido-isobornyl acrylates, Tetrahedron Lett. 25, 58855888.

21. Dussault, P. H., K. Trullinger, T., and Cho-Shultz, S. (2000) Chiral Silyl Ketene Acetals from Thioesters: Reaction with Acetals and Peroxyacetals to form 3-Alkoxy- and 3Peroxyalkanoates, Tetrahedron 56, 9213-9220.

22. Jin, H.-X., Liu, H.-H., Zhang, Q., and Wu, Y. (2005) On the Susceptibility of Organic Peroxy Bonds to Hydride Reduction, J. Org. Chem. 70, 4240-4247. 